E.L.U.A., 8, 1992, pp: 99-132

\title{
EL ARTE DICCIONARISTA DE SEBASTIÁN DE COVARRUBIAS ${ }^{*}$
}

\author{
JuAn CRESPo Hidalgo \\ (Universidad de Málaga)
}

\begin{abstract}
RESUMEN
The complete edition of the unpublished manuscript Suplemento al Tesoro de la lengua castellana by Sebastián de Covarrubias provides some necessary clues to the understanding of its author's lexicographic criteria and of a number of personal details, which, in the course of time, have made Covarrubias' work to be considered as something original and unique among the huge spanish lexicography. Those details of biographic, anecdotic, popular, gastronomic type do not constitute strictly lexicographical information, but this kind of information together with some other of purely lexicographical interest permits us to recompose Covarrubias' skill as a lexicographer, his everyday work in the making-up of the first monolingual dictionary of the Spanish language.
\end{abstract}

La edición completa del manuscrito inédito Suplemento al tesoro de la lengua española castellana de Sebastián de Covarrubias aporta claves necesarias para comprender los criterios lexicográficos de su autor, amén de numerosos datos personales, que han permitido, andando el tiempo, que la obra de Covarrubias sea inconfundible y original dentro del marco de la vastísima lexicografía española ${ }^{2}$.

* El presente trabajo es posible gracias a la licencia de investigación, concedida por la Consejería de Educación de la Junta de Andalucía, en el Departamento de Filología Española I y Filología Románica de la Facultad de Filosofía y Letras de la Universidad de Málaga.

1 La edición del manuscrito la hemos realizado dentro de la obra Edición y Estudio del Suplemento al Tesoro de la Lengua Española Castellana de Sebastián de Covarrubias. Ed. en microfichas de la Universidad de Málaga 1991.

2 Cfr. los catálogos del Conde de la Viñaza, Biblioteca histórica de lafilología castellana. 3 ts., Madrid 1893. Ed. facsímil, Madrid 1978, especialmente el t. III; Américo Castro, Glosarios latino-españoles de la Edad Media, Madrid 1936; Annamaria Gallina, Contributialla storia della lessicografia italo-spagnola dei secoli XVI e XVII, Florencia 1959; Samuel Gili Gaya, Tesoro lexicográfico (1492-1726), t. I, Madrid 1960, pp. XVII-XXXI; Manuel Alvar, «Lexicografía» en Enciclopedia de la cultura española, Madrid 1963, t. IV, pp. 38-40; Homero Serís, Bibliografía de la lingüística española, Bogotá 1964, pp. 399-510; 
Esos datos de interés biográfico, anecdótico, costumbrista, gastronómico, pensamientos, etc., son informaciones no estrictamente lexicográficas; pero, junto con otros de verdadero interés lexicográfico, que analizaremos a continuación, permiten recomponer el arte diccionarista ${ }^{3}$ de Covarrubias, 'el día a día' de la elaboración del Suplemento.

Joan Corominas y José A. Pascual, Diccionario crítico etimológico castellano e hispánico, 5 ts. publicados. Madrid 1980-1983, t.I, pp. XXXVII-LX; Martín Alonso, Enciclopedia del idioma. Diccionario histórico y moderno de la lengua española (siglos XII al XX), etimológico, regional e hispanoamericano. 3 ts. Madrid 1982, t. I, pp. XLIV-LXI; Maurizio Fabbri, A Bibliography of Hispanic Dictionaries. Imola 1979; Gisela Bialik Huberman, Mil obras de lingüistica española e hispanoamericana. Un ensayo de síntesis crítica, Madrid 1973, pp. 313-507; Diccionarios españoles, publicación del Instituto Nacional del Libro Español, Madrid 1980; Emanuel Molho, The Dictionary Catalogue, New York 1980; Julio Fernández-Sevilla, Problemas de lexicografía actual, Bogotá 1974, especialmente el último capítulo. Los trabajos de Manuel Alvar Ezquerra, citados a lo largo de este artículo y otros muchos que no han sido precisos para este caso concreto, constituyen, en su conjunto, una efectiva historia crítica de la lexicografía española. En cierto modo, la obra de Marta C. Ayala Castro, Edición y estudio del «Epítome del Tesoro de la lengua castellana» de Fray Juan de san José, editada en microfichas por la Universidad de Málaga en 1988, se puede utilizar como catálogo para el estudio de las Nomenclaturas.

3 Aunque, nuestro trabajo se centra en el Suplemento, en muchos casos, por la especial relación del manuscrito con el Tesoro, metodológicamente son precisas numerosas calicatas en éste, en búsqueda de datos contestes con los que estudiamos en el Suplemento, de forma que aporten más pruebas sobre nuestro lexicógrafo y su forma de trabajar. Cfr. lo que dice M. Alvar Ezquerra en la «Presentación» de Esteban de Terreros y Pando, Diccionario castellano con las voces de ciencias y artes, Ed. facsímil, Madrid 1987 , p. VIII: «Para nosotros no siempre es fácil averiguar cómo han trabajado los lexicógrafos de otras épocas, y sólo sabemos la manera de llevar a cabo su ejercicio de manera indirecta». Estas noticias indirectas, en el caso de Terreros, las legó a la posteridad un íntimo amigo del lexicógrafo; pero, por lo que toca a Covarrubias, carecemos de tales testimonios, no obstante, veremos que los métodos seguidos por ambos son muy similares, si comparamos los datos que extraemos de las obras de Covarrubias con los aportados por Alvar Ezquerra en el estudio anteriormente citado y con los numerosos testimonios que aporta en «La confección de diccionarios» en Voz y Letra, I, 1990, pp.47-76. Los primeros resultados deducidos de la colación del Tesoro con el Suplemento - y tangencialmente con sus Emblemas morales - son que el método seguido por Covarrubias es el mismo, y que la planta de sus obras se nutre de idénticas fuentes e informaciones, según las muestras siguientes. El Tesoro de la lengua catellana aparece citado en la Dedicatoria que Covarrubias hace de sus Emblemas al duque de Lerma de esta forma: «Estas son las primicias de mis trabajos que van saliendo a la luz: y tras ellas (siendo Dios servido) publicaré luego el Tesoro [...]»; y a lo largo de los Emblemas, cita al Tesoro en la Centuria II, $\mathrm{n}^{\circ}$. 45, glosando un emblema en el que figura el grabado de un elefante y una palmera: «No sucede menos al que en su imaginación, con fuerça de ingenio, fabrica alguna obra, parto del entendimiento, como yo lo he experimentado en mi tesoro de la lengua española, en que he trabajado muchos años hasta ponerlo en estado que pudiesse salir en público». En el emblema sesenta y cuatro de la segunda centuria, comentando la fábula del nacimiento de criaturas con ambos sexos, refiere que «desta materia tenemos dicho alguna cosa en el tesoro de la lengua Castellana $[\ldots] \gg$. Comentario semejante aparece en el emblema treinta y siete de la tercera centuria. Y, de nuevo, vuelve a citar al Tesoro en otro emblema en el que figura también el elefante en el grabado (recordemos que Covarrubias dedica al artículo ELEFANTE en el Tesoro una decena de folios), pero en este caso, con el otro nombre con el que se conoció el Tesoro en su época, como se refiere en la «Carta del Licenciado don Baltasar Sebastián Navarro de Arroyta» (fol. D v. del Tesoro), dirigida a Covarrubias y donde cita al Tesoro con el nombre de las Etymologías; pues bien, en el comentario del emblema 61 de la segunda centuria dice: «De la naturaleza del elefante, y de su historia, ay mucho escrito, y alguna cosa tocamos en nuestras etimologías [...]». Aunque no figura el Ms. citado en los Emblemas, sí existen elementos comunes entre los Emblemas, el Tesoro y el Suplemento. Los datos del comentario del emblema veintiséis de la primera centuria los encontramos de forma muy parecida en el artículo + ASBESTO del Suplemento y en la información del lema ENTERRAR del Tesoro. El comentario del emblema cincuenta 


\title{
LA OFICINA LEXICOGRÁFICA DE COVARRUBIAS
}

\section{A. Método de incorporación de las etimologías en el suplemento}

\author{
Muchas veces repite Covarrubias a lo largo del Tesoro de la lengua castellana
} $o$ española que lo correspondiente a su instituto ${ }^{4}$ es el estudio de las etimologías.

Covarrubias no procede en este estudio de forma precipitada, arbitraria o sin rigor, todo lo contrario, la parte de la microestructura del Suplemento al tesoro de

y cinco de la segunda centuria coincide literalmente, en gran parte, con el artículo dedicado en el Suplemento a * EROSTRATO, el hombre que quemó el templo de Diana en Éfeso, para ser famoso; pero en el emblema lo llama Erasístrato. Lo mismo sucede entre el artículo dedicado a * APELES y el emblema cuarenta de la primera centuria; y el mismo Covarrubias cita en el artículo correspondiente a la entrada * MILÓN su emblema cincuenta y seis de la centuria primera, cuya octava y comentario son los que forman el cuerpo del artículo de este lema. Igual relación existe entre el emblema setenta y uno de la primera centuria y el artículo* ANÓN del Suplemento; entre * ETEOCLES y el emblema ochenta y uno de la primera centuria; entre * CRESO y el emblema ${ }^{2} 98$, Centuria I; o entre * MIDAS y * FALARIS respectivamente con el comentario de los emblemas $n^{\text {os. }} 60$ y 70 de la Centuria II. Véase, sobre la importancia de los prólogos, prefacios y datos contenidos en la microestructura, a Julio Casares, Introducción a la lexicografía moderna, Madrid 1950, p. XV; Louis Cooper, «El recueil de Hornkens y los diccionarios de Palet y de Oudin» en NRFH, 3-4, 1962, p. 299; Bernard Quemada, Les dictionnaires du fransais moderne: 1539-1863. París 1968, pp. 17, 75-121, 300-302 y 465-469; Robert Verdonk, «Contribución al estudio de la lexicografía española en Flandes en el siglo XVII(1599-1705)», BRAE, LIX, 1979, pp. 299-369, sobre todo las pp. 332-335; los estudios sobre los diccionarios académicos de M. Alvar Ezquerra, «QQué es un diccionario? Al hilo de unas definiciones académicas» en $L E A$, II-1, 19,80, especialmente las páginas 115-118; «Los prólogos del Diccionario académico: nomenclatura específica y microestructura» en RFE, LXIII, Madrid 1983, 204-222; «El Diccionario de la Academia a través de sus prólogos: Los planteamientos y el vocabulario general», en Philologica Hispaniensia in honorem Manuel Alvar, t. II, Madrid 1985, pp. 33-44.

4 En el Tesoro, en el artículo dedicado a la letra $\mathbf{A}$, escribe Covarrubias: «Y juntamente pido con humildad y reconocimiento al pío letor perdone mis faltas y, como próximo, me advierta aquello en que yo huviere errado cerca de la interpretación y etimología de los vocablos. No embargante que hasta agora no sé que ninguno aya emprendido este trabajo, llevándole a cabo como yo pretendo, si Dios me diere su ayuda, salud y vida para proseguirlo y darle fin»; y en el art. CARIDAD declara: «Lo demás se dexa para los señores teólogos escolásticos, que no es mi intento divertirme de lo que en este trabajo professo, que es la etimología del vocablo». De forma parecida lo refiere en el art. CARNE. V. también con qué simpatía justifica que su obra se ocupe de saberes enciclopédicos s. v. ESPERANÇA: «[...] como lo tengo protestado en el principio desta obra, la qual no se endereça a tratar de las materias más de lo que toca a sus etimologías, y a algunas cositas que acompañen». Hemos subrayado las palabras «cerca de la interpretación» y el anterior diminutivo, para resaltar la fina ironía de Covarrubias al considerar la enorme cantidad de historias que nos cuenta en su obra, y que se ocupe de algo más que de las etimologías de los vocablos. En el artículo ROMANCE comenta, con motivo de la diversidad de lenguas y vocablos que existieron y existen en España, que: «Y de aquí se puede colegir quán gran trabajo ha sido y atrevimiento grande querer yo darles a todos sus orígenes»; s.v. VIEJO, el artículo se compone de una definición estrictamente lexicográfica, la etimología y un derivado con su correspondiente definición; pero le queda a nuestro lexicógrafo el resquemor de ser tan escueto y no poder alargarse, por lo que nos espeta: «Del hombre viejo y de la vejez, ay libros enteros $[\ldots]$ y assí viene a ser lugar común del que yo huyo, por no ser mi instituto más de lo que toca a las etymologías de los vocablos y al uso de ellos». De forma parecida se expresa en los artículos DUQUESA, GRACIA, LEY, MESTA, NOMBRE, VESTIDURA; peroen la palabra-entrada ORO se revuelve contra sus fuentes, pues todas se atribuyen ser el origen de la palabra ORO, y remata con: «[... ] yo he cumplido con mi obligación, y no pienso trabajar en descubrir las venas de la tierra [...]; no creo nada desto». 
la lengua Española Castellana dedicada a esclarecer las etimologías fue pensada y documentada por Covarrubias, según la bibliografía y método de la época ${ }^{5}$.

Así, los estudios de J. M. Lope Blanch, referidos a los indoamericanismos, germanismos, etc., en el Tesoro, han demostrado que no son tantos los errores de Covarrubias en esta materia; sobre todo, comparándolo con sus contemporáneos y con algunas obras posteriores ${ }^{6}$. Esto por una parte, pero por otra, Covarrubias

5 Cfr. al respecto, los testimonios que hemos entresacado del Tesoro donde, en el art. BODA, declara: «Algunos de estos verbos no he hallado en el Thessauro de la lengua santa; cada uno tomará lo que mejor le pareciere [...]». Otras veces, las referencias a sus fuentes son vagas e imprecisas, pero ello no les quita valor, así, en el art. CAPA, cuenta: «Cierto amigo dize, que es Hebreo, y viene del verbo [...]; yo no le he topado en el Thesauro. Otro del nombre $\kappa v \pi \alpha \zeta$, griego; tampoco le hallo en el Lexicón.»; en el art. CAPAR: «Algunos quieren que capar sea verbo hebreo [...]»; en COFRE: «Un curioso de la lengua hebrea dize [...]». Igual referencia s.v. GRAO. Con otra fórmula, en el art. CHUFA confiesa que: «Su etimología me la dio el maestro Pedro Juan Núñez, doctíssimo varón en lenguas [...]»; igualmente, en la voz ENARMONARSE: «como me advirtió Pedro de Valencia, coronista mayor de Su Magestad». Cuando la fuente es rara, la identifica con detalle para evitar confusiones al estudioso; pues, en MATIZAR reseña: «Este verbo hallé en un Lexicón Griego impresso en León, año de mil y quinientos y cincuenta y tres, apud Ionanem Frellonium. Y esto he dicho por si alguno le estrañare.»; también lo cita en el art. ORO. Efectúa una verdadera labor de campo y pregunta a los peritos en la materia, como en el caso de ESPARAVÁN: «No me han sabido dar razón de su etimología los albéitares hasta agora». Pero, a veces, parece citar de memoria, JARDÍN: «El padre Guadix, si no me engaño, dize ser Arábigo». Sin embargo, como buen estudioso e investigador, no se conforma fácilmente, como se aprecia en ESMALTE en cuyo artículo, tras discutir su etimología, afirma: «[...] pero no quedo desto muy satisfecho.»; o en el art. FILATERÍA, donde declara: «No inoro lo que otros han dicho sobre la etimología desta palabra [...]»; s.v. GARRAFA refiere: «[...] no he hallado tal nombre»; y no ahorra esfuerzos por lo que cuenta en GRAMALLA: "Y con ser tan común este nombre, no hallé en Valencia, ni Zaragoza, ni en Barcelona, quien me diese razón de su etimología». Reconoce Covarrubias lo difícil que es dar origen a todas las palabras, y así lo declara en el art. PANTORRLLLA: «No me atrevo a darle etimología, si no es formándola de griego y español, que lo tengo por disparate, [...]»; igual manifiesta s.v. TIZNADO. Testimonios contestes de los anteriores, que confirman el método lexicográfico de Covarrubias, encontramos en el art. AÇAFRÁN: «He comunicado la etimología del nombre açafrán con grandes arábigos, y concuerdan no ser propio, porque no tiene raíz de verbo, y es común a turcos, persas y árabes, y, [...]. Yo entiendo ser de raíz hebrea [...]». Parecidas fórmulas se hallan en los arts. AÇOTE, AÇUDA, ADARGA, AFÁN, ALBUFERA, ALMÁRTEGA, AZECALAR, AZECHE. Sus dudas las expone s.v. ACECHAR con la fórmula: «pero no me quadra la composición»; ejemplos similares tenemos en los arts. ALMONEDA, BERVÍ; y al contrario, s.v. ALCANÇAR comenta la etimología que le da Juan López de Velasco con «y no me descontenta la etimología», o en AÇOR reseña: «En cierto libro manuscripto que trata de cetrería, hallé escrito aver tomado nombre [...]». Covarrubias consulta a cualquiera que le pueda dar información, así lo cuenta s.v. AGUINALDO: «Y por dezir todo lo que me han comunicado, un hombre docto y curioso me dixo que este vocablo estaba corrompido de aglando [...]»; pero no tuvo tanta suerte con la voz CAYMÁN, donde dice: «[...] no me han sabido dar su etimología.», o s.v. CADILLOS: «Este vocablo es muy común y cierto entre texedores y gente de la lana, y yo reparé en él porque para atar unas parras de mi huerta, me truxeron destos cadillos, y nadie me supo hasta oy dar su origen o etimología»; otras veces tiene más fortuna, como en el art. ALCALÁ DE HENARES donde comenta: «viene bien la etimología que un gran arábigo me dixo». Y, por fin, nunca deja de citar, si el caso lo requiere, la autoridad de Diego de Urrea, con la alusión llena de respeto que vemos en el art. ALAMBIQUE: «Yo doy mucho crédito a Urrea, porque sabe la lengua magistralmente. Parecido es lo que dice en ALBACEA, ALCORÁN. ALGUAZIL, ALMALAFA, ALQUICEL.

6 Cfr. J. M. Lope Blanch quien muestra que «Muchos de sus errores proceden de las fuentes que estaban a su alcance. Y en no pocos casos, atina donde otros - inclusive décadas después- yerran. [...] $/ /[\ldots]$ Covarrubias [...] 5 errores, 7 aciertos y dos aciertos a medias [...]. En cambio Mayáns [sic], un siglo y cuarto después, se acredita un solo acierto (tacaño) y 14 errores. Y aún se consideraba autorizado para 
es consciente de que la etimología es materia resbaladiza, de particular saber y dedicación, y, consecuentemente, no duda a lo largo del Suplemento en declarar con estilo directo, coloquial y campechano sus nuevos hallazgos, dudas, o ignorancia ${ }^{7}$. Veamos algunas muestras de su método de trabajo.

La autoridad del padre Mariana es discretamente objetada en el artículo correspondiente al añadido de la voz + CAPITÁN , de contenido exclusivamente etimológico, con la frase: «pero a mí me quadra más la arriba dicho» ${ }^{8}$.

De forma más sesuda y adecuadamente documentado, contradice la etimología del lema + ÇARABANDA que encuentra en el doctor Alonso López Pinciano ${ }^{9}$, ya que argumenta:

juzgar la obra del toledano como Thesauri Carbones.» pp. 299-301 de «Los indoamericanismos en el Tesoro de Covarrubias» en NRFH, XXVI (1977), pp. 296-315; y en el artículo «Sebastián de Covarrubias y el elemento germánico del español» en Anuario de Letras, XV, México 1977, pp. 249-257 concluye: «No queda tan malparado nuestro lexicógrafo, especialmente si consideramos que el cotejo se ha hecho en un terreno que no le era familiar» (p. 252); o de forma más rotunda se expresa Lope Blanch en «El juicio de Ménage sobre las etimologías de Covarrubias», Homenaje a Kurt Baldinger, Tübingen 1979, pp. 78-83, al afirmar que $\ll[\ldots]$ no podría deducirse que la labor etimologizante del francés [Ménage] supere de manera rotunda a la del español [...]. Dentro de su época, la labor etimológica cumplida por Covarrubias tiene un positivo valor, y no desmerece esencialmente ante la de sus contemporáneos.» (p. 83); parecidos argumentos favorables a Covarrubias se encuentran en otro estudio de Lope Blanch: «Otro aspecto de la relación entre Ménage y Covarrubias», en Actas del V Congreso de la Asociación de Lingüística y Filología de America Latina, Caracas 1986, pp. 393-400. Sobre el problema e historia de la inclusión de las etimologías en el diccionario, trata J. Casares, Introducción a la lexicografía moderna, Madrid 1950 , pp. 29-49; M. Alvar Ezquerra, «Diccionario y Gramática», en $L E A$, IV, 1972, pp. 181-184.

7 He aquí algunas muestras similares del Tesoro: en el art. ALCAUDETE dice: «y no sé su etimología». Formas parecidas se encuentran en BOLLOMAIMÓN, BRENAA, CASPA. Otra forma de expresar sus dudas la vemos en el art. ACECHAR: «pero no me quadra la composición»; también afirma «no me quadra» en los arts. ALMONEDA, BERVI. Pero no podían faltar muestras del gracejo del canónigo de Cuenca, que en el art. LOCO declara: «La etimología deste vocablo tornará loco a qualquier hombre cuerdo»; y s.v. RINCÓN: «La etymología de rincón está tan arrinconada que hasta aora yo no la he hallado»; o, cuando con ingenuidad, afirma s.v. CRISTIANO: «Quiero advertir una niñería y no dexa de ser curiosidad». Otra perla de su ironía la tenemos en el art. MULTA. Su estilo directo, coloquial, narrativo y campechano aflora en la monografía que dedica a ELEFANTE (fol. 339v.): «Como este animal es tan grande y tan misterioso ha sido el discurso a medida de su grandeza». Y, en contraste con el anterior argumento, no deja de ser chistosa la razón siguiente inserta en el art. ESCARAVAJO donde, tras la definición, etimología, breve información enciclopédica, referir que sobre los escarabajos trata Plinio, que hay algunas cosas que decir y no es justo pasar a otra dicción, pues ESCARAVAJO «parece estarme diziendo, Aunque negros gente somos», se extiende largamente en curiosidades sobre este insecto. En el art. GUSTO refiere: «No nos derramemos a más, sino concluyamos, porque esta letra $\mathbf{G}$. quede con gusto». Cfr. M. Seco, «Un lexicógrafo de la generación de Cervantes. (Notas sobre el Tesoro de Covarrubias)» en Instituto de Bachillerato Cervantes. Miscelánea en su cincuentenario (1931-1981), Madrid 1982, p. 237 y n. 27. Compárese con el método del lexicógrafo canario José Viera y Clavijo estudiado por M. Alvar, La lengua como libertad y otros estudios, Madrid 1982, pp. 146-166, y por M. Alvar Ezquerra en «Ictionimia en el Diccionario de Historia natural de Viera y Clavijo» en Actas del V Congreso Internacional de Estudios Lingüísticos del Mediterráneo, Madrid 1977, pp. 233-267. V. también Asunción Rallo Gruss, Antonio de Guevara en su contexto renacentista, Barcelona 1979, p. 219.

8 Este «arriba dicho» se refiere al nuevo Tesoro que él 'veía impreso y dispuesto tipográficamente' en una futura edición junto con el Suplemento al tesoro de la lengua Española Castellana. Otra prueba de esta futura impresión la vemos en el art. * CALICVT: «Dio nombre a la tela que tenemos dicho», se refiere al art. del Tesoro CALICVD.

9 Véase este autor en el apartado «Autoridades en el Suplemento» en la edición en microfichas de nuestra $o . c$. 
No me quadra mucho, porque la conuersión de Çarabanda en Dithirámbica es muy forçada.

Pero de esta palabra Covarrubias ya había dado otra etimología de origen hebreo en el Tesoro, y podía haberse contentado con emparentarla con la lengua madre y hubiese cumplido con su "instituto" ${ }^{10}$; pero no lo dejó ahí, sino que acarreó nuevos materiales del médico Gerónimo de Huerta ${ }^{11}$, mas, como no se queda muy convencido, remata con: «Esta Etymología me pareçe más llana si fuese verdadera». Corominas ${ }^{12}$ y el Diccionario Actual de la lengua española $(V O X)^{13}$ registran origen incierto para la voz zarabanda, y el Diccionario de la lengua española ${ }^{14}$ de la Real Academia Española le atribuye origen onomatopéyico; luego, está claro el esfuerzo de Covarrubias por buscarle un origen a la entrada + ÇARABANDA.

En el caso de la etimología de la voz * CUESCO, que tanto Corominas como el diccionario académico ${ }^{15}$ le dan origen onomatopéyico, Covarrubias, con la fórmula propia de dar su opinión: «Yo tengo para mí que $[\ldots]^{16}$, propone una atrevida etimología para evitar tener que aplicarle el rótulo de voz onomatopéyica ${ }^{17}$, $y$ darle origen latino.

De parecida forma procede en la voz + CASILDA, cuya etimología había dado Covarrubias en el Tesoro, haciéndole proceder, según su entender, del godo; y también incluye en este artículo que algunos le dan origen hebreo; pero en el Suplemento Covarrubias es más rotundo y afirma:

Ultra de lo dicho yo tengo por çierto ser este nombre Arábigo ${ }^{18}$.

Más evidente resulta su intención de ofrecer la mayor documentación posible sobre las etimologías en el caso de la palabra + ÇEBRA, pues en el Tesoro decía, en el correspondiente artículo, que ignoraba su etimología, pero en el añadido del

${ }^{10}$ Cfr. F. Lázaro Carreter, Las ideas lingüísticas en España durante el siglo XVIII, Madrid 1949 (manejamos la 2: ed., Madrid 1985, pp. 109-130); los estudios de Lope Blanch citados antes, y W. Bahner, La lingüística española del siglo de oro, Madrid 1966, pp. 25-27 y 101-117.

$11 \mathrm{~V}$. este autor en el capítulo «Autoridades en el Suplemento» de mi $o . c$.

12 J. Corominas, Breve diccionario de la lengua castellana, Madrid 1967, s.v. zarabanda.

${ }^{13}$ Barcelona 1990. Dirigido por M. Alvar Ezquerra.

14 V. Real Academia Española, Diccionario de la lengua española, Madrid ${ }^{20} 1984$, s. v. zarabanda.

${ }^{15} \mathrm{~V}$. la nota anterior. Esta palabra no figura en la nomenclatura de la obra de V. García de Diego, Diccionario etimológico español e hispánico, 2 ed. a cargo de Carmen García de Diego, Madrid 1985.

${ }^{16}$ De forma similar se expresa en el Tesoro en los arts. CEBRA y TORRE DE LODONES. Son muy pocas las veces que Covarrubias atribuya el origen de una palabra a la onomatopeya; según nuestras calicatas, lo hace en el caso de las voces CRUGIR, CENCERRO, CHIRRIAR, ESTALLIDO; GRITA, MORMULLO, MURMULLO, PÍAR, REÇONGAR.

${ }_{17}$ Pero, en contraste, compárese con la sensatez que muestra al atribuir en el añadido del Suplemento origen a la palabra-entrada + CEBRA, que analizamos párrafos más abajo.

${ }_{18}$ Fol. 96v., art. + CASILDA del Suplemento. 
manuscrito ya había encontrađo datos sobre los orígenes de CEBRA en las obras de Marineo Sículo, Varrón, Plinio ${ }^{19}$. Trasladadas al Suplemento las citas, concluye con la fórmula que ya hemos visto:

Yo tengo para mí que todo esto es fabuloso y auerse dicho solo para encareçer la veloçidad de los caballos Españoles [...].

No cae Covarrubias en la patriotería de atribuir la paternidad de las yeguas españolas al viento céfiro, y por intermedio de 'céfiras' llamarse 'cebras'.

En el artículo de la palabra-entrada + DIADEMA también advierte Covarrubias que la etimología recogida en el manuscrito es moral y que la propia es la que ya dio en el Tesoro.

En conclusión, Covarrubias no se ciñe a coleccionar información sin una crítica por su parte, sino que, cuando le faltan las razones, los conocimientos específicos o no ha encontrado información, no duda en confesar de ciertas palabras del Suplemento lo siguiente:

\section{* CATALUFA:}

[...] nombre cuya Etymología yo ignoro por ser vocablo peregrino y estrangero. + ÇAPATO:

Y no sabría determinar si tomó este nombre de los Castellanos nuestros o nosotros de ellos.

* ENXECO:

Preçisamente no sabría darle su Etymología aunque sospecho ser nombre Arábigo.

\section{+ GIGOTE:}

Con todo eso no desecho la Etymología puesta en la palabra Quixotes [...]. * LÚAS:

Precisamente yo no sabría dar la etymología de este vocablo, auráse/ de consultar con los Portugueses.

\section{B. Fórmulas declarativas del método personal de investigación de Covarrubias en la microestructura del suplemento}

Por las muestras anteriores, y las que vamos a estudiar a continuación, comprobamos que Covarrubias procura dejar claro el material lexicográfico elaborado por él, asomándose en primera persona a la microestructura del Suplemento al tesoro de la lengua Española castellana.

${ }^{19} \mathrm{~V}$. estos autores en el capítulo «Autoridades en el Suplemento» de mi o.c. Cfr. la similitud entre el método y 'oficina de Covarrubias' y el 'gabinete de trabajo' de José Viera y Clavijo en la o.c. de M. Alvar, pp. 146-166; una visión general de los métodos seguidos en la confección de los principales diccionarios en el art. cit. de M. Alvar Ezquerra de la n. 3. «La confección [...]». 
En cuanto a las etimologías, en la voz * ADRASTIA tercia en los datos etimológicos incluidos en este artículo con la fórmula «A mí me pareçe podría auerse dicho $[\ldots]{ }^{20}$, en el artículo * ALBANIA lo hace así:

Esta opinión para mí no es de mucho fundamento porque muy más verisímil es que tomó el nombre de [...].

En el añadido a la voz + LUSITANIA, tras las citas de Bernardo de Aldrete y Manuel Correa, concluye, refiriéndose a la etimología propuesta por Correa, con la frase «No me quadra $»^{21}$.

En el caso de la voz + BAHARÍ, Covarrubias media en las opiniones del padre Guadix y Francisco López Tamarid y afirma:

$[\ldots]$ a mí me parece sin embargo de lo dicho ser nombre Hebreo $[\ldots]^{22}$.

Igualmente vuelve a dar su opinión en favor del hebreo en el caso de la palabra + BETIS:

Yo no alcanço más de lo que tengo dicho [...].

y vuelve a referir los datos del Tesoro.

En el artículo correspondiente al lema + BELLÓN añade datos enciclopédicos a la definición de Nebrija en apoyo de su propuesta etimológica:

Por más cierto tengo auer trahído principio de la primera moneda que se acuñó en Roma [...] con la effigie de vna oueja [...] cubierta con el vellón de su lana se llamó después moneda de Bellón [...].

Esta forma honrada de trabajar es palpable en la franqueza que muestra en los casos como en el añadido + ALGARBE, en el que refiere que:

Pero yo doy mucho crédito a lo que Diego de Urrea me comunicó, especialmente dando raçón de los vocablos y de sus Etymologías.

Y más claramente en el artículo * HANEGA:

E consultado nuebamente esta palabra con Diego de Urrea, y diçe traher origen del verbo Arábigo Fenege que significa ablentar $[\ldots]^{23}$.

${ }^{20}$ En el apartado anterior, para otras pruebas, citamos ejemplos similares a estos.

${ }^{21}$ Cfr. con las anotaciones que hacemos en el apartado anterior a las formas de declarar Covarrubias sus dudas o ignorancia en algunos casos.

22 Su defensa del hebreo siempre está dispuesta, como en el art. COSCOJA dice: «Esto no contradize a que no sea tomado de la lengua hebrea, siendo la madre de todas». De forma parecida lo hace en ÇAMORA, ÇAQUE, CHAVACANO, ENCARAMAR, GIBA, IARA (jARA), REHENES, SIRENAS. V. también en el Tesoro (1611) el fol. H r. «Dedicatoria al rey Felipe III».

${ }^{23} \mathrm{~V}$. al final de la n. 5 los testimonios que recogemos sobre Urrea, además de lo que Covarrubias dice sobre éste en el fol. I r. «Al Letor» de la edición de 1611 del Tesoro y en el art. ÇAGAL. 


\section{Método de inclusión del material enciclopédico}

Como en las etimologías, Covarrubias tiene sus preferencias a la hora de dar crédito a uno u otro historiador ${ }^{24}$, así, declara en el artículo + ALFONSO (fol. 19 r) que en la lista de los alfonsos él no incluye a don Alonso, rey de Aragón, como lo hacen Garibay y otros, pues él sigue al padre Mariana.

Y en el artículo de la palabra-entrada + ANATEMA dice:

Yo seguí lo más çierto según declara el Cardenal Toledo sobre el dicho Capítulo [...] lo mismo diçe Dionisio Cartuxano eodem loco ${ }^{25}$.

Al contrastar los datos del padre Mariana, que refiere de los hombres del pueblo del mismo nombre del lema + BELILLA que están persuadidos de que una campana que allí hay se mueve sola para anunciar grandes acontecimientos, dice Covarrubias con gran prudencia:

[...] Yo no trato de la verdad que esto tiene ni la tomo a mi cargo. Consta oír lo menos que autores graues lo refieren y que citan testigos de vista de aquel milagro ${ }^{26}$.

Y en el añadido al lema + AVICENA, al final del artículo, como observa que son datos contradictorios manifiesta que «no concuerda con lo que emos dicho, lo qual es de Conrrado en su Bibliotheca ${ }^{27}$.

Este afán de documentarse exhaustivamente, confrontar las distintas fuentes y extraer una conclusión personal lo volvemos a encontrar s. v. * CIMEROS, en cuyo artículo, comentando un pasaje de Virgilio, refiere:

Y a mí pareçer aquí se deuía encaminar la pregunta Enigmática de Dametas pastor de la terçera Egloga de Virgilio [...]. No voy contra lo que en este lugar diçen los Comentadores de Virgilio ni contra Seruio, [...] Francisco Sánchez, el Brocense $[\ldots]^{28}$.

${ }^{24}$ Compárese con los párrafos anteriores y la n. anterior.

${ }^{25}$ V. lo que confiesa en el Tesoro en los art. ARCHITRICLINIO: «Hame sido fuerça traer todas estas opiniones para cumplir mi obligación [...]»; ALMOFAR: «Lo que he podido averiguar desto es lo que se halla escrito en la Corónica del Rey don Rodrigo». V. también los arts. ALQUIMIA, ALUMBRE, y las notas 5 y 27.

${ }^{26}$ Comp. con lo que dice Covarrubias en el art. AOJAR del Tesoro y en el añadido + AOJAR del Suplemento.

27 V. en el Tesoro y en el Suplemento el art. AVICENA. Su honradez científica muestra un preciso ejemplos.v.CRONOGRAPHÍA: «En nuestros tiempos ha escrito Gilberto Genebrardo una Chronographía, obra famosa y erudita, de la cual yo me aprovecho mucho en este mi trabajo».

${ }^{28}$ Argumentos parecidos esgrime Covarrubias en el Tesoro en el art. CLAVO: «Yo entiendo este epigrama en este sentido, aunque los comentos vay an por otro camino»; y en el art. ALAMBRE, Covarrubias advierte cierto fallo en un traductor, pero no da su nombre porque «no soy amigo de lastimar a nadie, especialmente pudiéndose desquitar presto, pues a cada hoja hallarán en este mi trabajo muchas faitas». No obstante, en el art. TUFO comenta: «No puedo dexar de reyrme de un comentador del Petrarca [...]. 
No se conforma Covarrubias con recoger datos para sus monografías de los libros a su alcance como dice al final del artículo dedicado a + MIÑO: «refiero lo que hallo impreso" ${ }^{29}$; sino que, cuando lo precisa, consulta ${ }^{30}$ a los expertos y técnicos en la materia correspondiente al vocablo en cuestión, de esta forma descubre en el artículo * BOSQUETEROS su método de trabajo:

Empero, aueriguando que cosa sean reales Bosqueteros, soy informado que con çiertas aguas fuertes en que echan el real, puesto después sobre la lumbre despide de sí vna hoja delgada [...], me pareçe que este término es metaphórico.

Por lo que respecta a la inclusión de nuevas acepciones, en ocasiones, como en el añadido al lema + CONDUCHO, no tiene inconveniente en rectificar casi la totalidad de todo el artículo del Tesoro:

Sin enbargo de lo dicho hallo que conducho y Condumio es todo vna cosa y vale lo que se da en comida [...].

Los límites geográficos de uso de una determinada palabra-entrada correspondiente a un nombre de cosa la inserta en la información enciclopédica del lema* AZIGE:

Cierta tierra con que se tiñen las lanas y los paños de negro [...]. Yo presumo ser lo mesmo que llamamos en Castilla tierra de Seuilla ${ }^{31}$.

${ }^{29} \mathrm{~V}$. notas 25 y 27 , y contrástense con la enorme curiosidad científica lexicográfica y el especial gracejo de nuestro lexicógrafo que nos descubre en el Tesoro aspectos de su forma de trabajar en el art. BADIL, donde dice: «Badilazo, golpe que el cozinero suele dar con el badil a los perros que se le entran en la cozina. $Y$ heme acordado de esta menudencia por lo que aquí diré», y a continuación cuenta una anécdota apropiada. De forma parecida procedió en el caso de la voz CADILLOS: «Este vocablo es muy común y cierto entre texedores y gente de la lana, y yo reparé en él porque para atar unas parras de mi huerta, me truxeron destos cadillos, y nadie me supo hasta oy dar su origen o etimología». Sobre las cualidades que debe poseer el buen lexicógrafo, cfr. J. Casares, o. c., Madrid 1950, pp. 24-26; M. Seco, Estudios de lexicografia española, Madrid 1987, pp. 81-83.

${ }^{30}$ Sobre la colaboración de los técnicos y el problema de los tecnicismos, cfr. J. Casares, o.c.,pp. 292-293; M. Alvar, o. c. en n. 7, p. 151; F. Lázaro Carreter, Estudios de lingüística, Madrid 1980, pp. 112-113; J. Fernández-Sevilla, o. c., pp. 115-156; M. Alvar Ezquerra en la «Presentación» de la o.c. en la nota 3, pp. VIII y XVI, especialmente esta última, y un tratamiento general enla obra de este mismo autor Proyecto de lexicografía española, Barcelona 1976, pp. 183-197; M. Seco, o.c., pp. 82 ss.; Jean et Claude Dubois, Introduction à la lexicographie: le dictionnaire, París 1971, pp. 18-23; A. Rey, Le lexique: images et modèles. Du dictionnaire à la lexicographie, París 1977, pp. 171 y ss.; G. Haensch, L. Wolf, S. Ettinger y R. Werner, La lexicografía. De la lingüística teórica a la lexicografíapráctica, Madrid 1982, pp.446-448.

31 V. mi art. «La vida y el pensamiento de Covarrubias como parte de la microestructura del Suplemento al Tesoro de la lengua Española castellana» en BRAE (en prensa). Cfr. M. Alvar Ezquerra, «Los regionalismos en los diccionarios y vocabularios regionales» en Lenguas peninsulares y proyección hispánica, Coordinador M. Alvar, Fundación Friedrich Ebert, Instituto de Cooperación Iberoamericana, Madrid 1986, p. 180. 
Esta predisposición a rastrear las distintas acepciones de las palabras la había cultivado Covarrubias por medio de su afición al estudio de los clásicos ${ }^{32}$, de la traducción, pues en el artículo de la dicción * FEACES recoge estos detalles:

Sospecho que a los Pheaces los podíamos llamar por esta raçón blancos y que la palabra albus en Martial, lib. 1. Epig. 56. signifique al ciudadano que por no salir al Campo al sol ni al ayre está con rostro blanco [...]. No ignoro que otros interpreten la palabra albus quasi solicitus et anxius, según Calderino, y que otros interpreten candidatus que vale tanto como pretendiente de officios.

Pero no siempre encuentra razones para aclarar la vinculación de ciertas palabras con hechos o personajes que le dotasen de un determinado significado o significante, como en el caso de la palabra-entrada * LICINIO donde figura como subentrada la palabra LICINIANAS, cuyo significado no recoge, y dice:

De estos Licinios dicen ser descendientes los que llamamos LICINIANAS. no sé yo el fundamento que aya para esto ${ }^{33}$.

La fama de Covarrubias como 'develador' del significado de las palabras la publica en el artículo dedicado a * LILAO:

Este es vn término vulgaríssimo, apicarado y casi de la Germania $[\ldots]$. Preguntáronme lo que podía significar.

Y como no pierde ocasión para mostrar su proverbial facundia, con cierta gracia, comenta del individuo nombrado en el lema * LINCEO que, según cuentan, podía ver lo que estaba detrás de la pared:

Si puede vno ver naturalmente lo que está de la otra parte de la pared o debajo de tierra no me toca a mí aueriguarlo. Con todo eso digo que es imposible si no es interuiniendo arte del demonio.

La concepción de diccionario enciclopédico, en parte, y de enciclopedia la demostramos en el apartado que dedicamos después al estudio de los añadidos, pero especial valor tiene el artículo + FERNANDO, y no sobra repetir que allí decía que

Atemoriçado con la multitud de cosas a que auía de acudir desconfiando pudiera llegar al fin y cumplimiento de esta obra fui atrancando mucho de lo que auía de decir $[\ldots]^{34}$.

${ }^{32}$ Compárese con la n. 28 y las referencias a sus obras que incluimos nuestro art. cit. antes. V. también los ejemplos que recoge M. Alvar en la $0 . c$. en la n. 7, p. 112 ss., sobre la forma certera de interpretar Covarrubias ciertas palabras.

33 V. la nota 7. En otros arts. del Tesoro, como CORDOVÁN, ataja las prolijas discusiones etimológicas con «No es negocio de mucha importancia, cada uno escogerá lo que mejor le pareciere»; o en ESMALTE, que tras discutir su etimología, afirma: «[...] pero no quedo desto muy satisfecho». De forma parecida se expresa s.v. CARCAÑAL.

${ }^{34}$ V. lo que digo en mi art. cit., sobre la salud de Covarrubias, y la reproducción fotográfica de una carta inédita, escrita días antes de su muerte. 
Pues bien, el lema + MELLIZOS es definido de forma escueta y perfecta en el Tesoro, con una definición estrictamente lexicográfica, con glosa etimológica breve y característica de Covarrubias; pero ya no debería tener tanta prisa, ni estar tan mal de salud ${ }^{35}$ porque no repara en citarse a sí mismo a la cabeza de varios autores que cuentan historias de mellizos, y relatar que $[\ldots]$.

[...] de dos hermanos Quiñones naçidos de vn parto oy decir ser tan parecidos

Es evidente, a la vista de los datos anteriores, su predisposición a la información enciclopédica, y, también lo es que Covarrubias podía haber aumentado fácilmente el número de entradas del Tesoro ${ }^{36}$ y del Suplemento, si hubiese acortado la información enciclopédica a lo largo de toda su obra, como lo hace en el Tesoro entre las letras $\mathbf{M}$ a la $\mathbf{Z}^{37}$, aunque, por lo que podemos deducir de la proporción del léxico incorporado en las letras que se repiten en el Tesoro y el Suplemento, la intención de Covarrubias fue añadir la información enciclopédi$\mathrm{ca}^{38}$ que había acumulado para la primera edición y que no utilizó, amén de que el canónigo de Cuenca no pretendió ser exhaustivo en inventariar el léxico ${ }^{39}$.

${ }^{35}$ Véanse el párrafo y nota anteriores.

${ }^{36}$ F. Lázaro Carreter, o.c. p. 113, cuenta en el Tesoro 11.000 entradas, incluidas las adiciones de Noydens; M. C. Ayala Castro en las pp. 299-300 de la o. c. encuentra 10.440, pero «Las palabras que se repiten varias veces como entradas de artículos se han contabilizado una sola vez» (p. 303, n. 7); Margherita Morreale, «Virgilio en el Tesoro de Sebastán de Covarrubias» en BRAE, t. LXVIIL, 1988, p. 206, nota 10, suma 11.261 artículos (no especifica si en dicha cifra se comprenden o no las adiciones de Noydens); pero estas cantidades pueden aumentar, como M. Seco señala en la p. 242, n. 42 de la $o$. $c$. en la nota 7: «Según mi recuento del índice elaborado por RIQUER, son 16.929 (cifra que no corresponde a la de entradas, ya que con frecuencia una de estas incluye, con definiciones, una familia léxica).»; por nuestra parte, y fruto del continuo contraste de las palabras del Suplemento con el Tesoro, en busca de conseguir el registro interno de las voces contenidas en el Manuscrito - voces, que, aunque no sean entradas, posean definiciones, su significado se desprenda por el contexto, sean raras documentaciones de voces naturales, expresiones pluriverbales, metáforas, etc.; contengan distintas acepciones al Tesoro, o muestren distintas grafías, variaciones de habla-, hemos encontrado unas doscientas cincuenta nuevas entradas que faltan en el índice de Martín de Riquer y que podemos sumar a las más de quinientas voces de todo tipo y refranes que hemos entresacado del texto del Suplemento para elaborar el registro interno que, integrado con la nomenclatura de este, preste la misma utilidad de consulta que el citado índice de la edición del Tesoro de M. de Riquer; luego, la suma de los índices totales del Tesoro más el Suplemento alcanzaría unas veinte mil palabras.

${ }^{37}$ Según nuestro recuento, de la letra $\mathbf{A}$ a la $\mathbf{L}$ aparecen, excluidas las entradas añadidas por Noydens (p. e. BeSUGUeTe, BOGA, CONSERVAR, CARACOLES, CARNESTOLENDAS, FARISEO, SALVATIERRA, SALVIA, etc.), aproximadamente 6.546 entradas en 754 páginas; mientras que de la $\mathbf{M}$ a la $\mathbf{Z}$, inventariamos 3.892 entradas en 243 páginas; hechas las cuentas, se observa que en la segunda parte incluye casi el doble de palabras-entrada por página.

38 V. los apartados V y VI del capítulo «La nomenclatura del Suplemento» de mi o. c., pp. 905-1001.

${ }^{39}$ Cfr. con lo que dice en el Tesoro en el art. ÉNFASI: «Esta palabra y otras muchas escusara yo de poner aquí, si en nuestro vulgar no estuvieran tan introduzidas» y en el art. CONSONAR: «Consonancia, disonancia, consonante, asonante. No reparo en estos vocablos por ser clara y notoria su sinificación y etimología, de con y sono. as.» Es evidente que Covarrubias, de haber tenido tiempo, hubiese aumentado fácilmente la macroestructura del Tesoro si hubiese sido exhaustivo en el método que empleó para la inclusión de nuevas entradas en el Suplemento; pero pesaron más en él las reseñas verbales a las que se refiere en el art. + FERNANDO del Suplemento. V. las pp. 908-915 de mi o.c. 


\section{Donde justifica no extenderse, pero se extiende}

Quevedo ${ }^{40}$, con su hiriente gracejo, le colgó al Tesoro el sambenito de obra en la que «el papel es más que la razón», y esta no le falta a Quevedo, pues ya en el Tesoro, una y otra vez, Covarrubias se propone no extenderse más allá de la tarea que se ha impuesto, otro tanto ocurre en el Suplemento, como vamos a ver.

A veces, cumple su propósito como en la glosa de la voz + ALBA:

Si mi instituto fuera escreuir historia muy gran campo se me auía descubierto en sola esta diç̧ión. Pero déjolo para los Coronistas de nuestros tiempos a cuyo cargo está escreuir las haçañas de estos príncipes. De esta mesma casa son los Condes de Fuentes ${ }^{41}$.

$Y$ efectivamente no se extiende.

En el artículo * BRUSELAS afirma que

[...] y por ser tan notorio todo lo que aquí puedo decir de ella lo paso en silençio, contentándome con darle su Etymología [...].

Efectivamente, tras dar la etimología, concluye brevemente el artículo ${ }^{42}$. Insiste en esta intención de brevedad en el artículo * CURETES:

Otras Etymologías les dan que no pongo aquí por no cansar. Estos eran sacerdotes de Cybeles en Creta ${ }^{43}$.

Igual referencia al cansancio de los lectores emplea en los artículos * DEMETRIO, o + FELIPE. Pero no siempre puede Covarrubias cumplir su próposito, y valiéndose de cualquier referencia, toma la vez y se despacha a su gusto, como lo hace en el lema + GAVÁN, cuyo artículo comienza diciendo

${ }^{40}$ V. el art. de J. M. Lope Blanch, «El juicio de Ménage [...]» art. cit, p. 78 ss.

${ }^{41}$ Este propósito tenía Covarrubias desde el principio de su obra, pues en el art. ADÁN del Tesoro confiesa: «Voy siempre con miedo y recato de no traspassar los límites de mi instituto, y por esta causa no me alargo a más», pero, con una ojeada a la microestructura del Tesoro y del Suplemento, se ve que no lo cumplió escrupulosamente. V. también la nota siguiente.

${ }^{42}$ En el Tesoro ya se encuentran argumentos similares en los artículos CANDELA: «Y porque mi instituto no es tratar las materias ad longum, sino tan solamente las etymologías de los vocablos, y lo que para ilustración desto es necessario, no me alargo más [...]». El subrayado es nuestro. Compárese con el comentario que hacemos a los subrayados de la n. 4. En el art. CRUZ, se detiene y afirma: «[...] y es justo no exceder de nuestro instituto»; o en HIERRO: «cerca de esta edad y de sus miserias y trabajos, ay escrito mucho, y experimentado; no tengo que detenerme en ello». Otros ejemplos tenemos en los arts. ARCABUZ, donde, tras un sinfín de citas enciclopédicas, remata: «Acudiendo a mi obligación, que es dar los orígenes de los vocablos [...]»; AVARIENTO: «y para cumplir con mi instituto esto basta»; AULA: «Dexemos esto que no es de nuestro instituto». Parecidas referencias encontramos en BAPTISMO, CUERNO, CEDRO, CENIZA, DOLOR, DUQUESA, ESPAÑA, HUERCO, HUMILDE, IRLANDA, IRREGULAR, ISLA, MANO, MENTIR, MURO, SANTIAGO, TIRANDO.

${ }_{43}$ De forma parecida escribía en el Tesoro en el art. ABÍAS: «[...] y lo demás, que por no cansar no refiero aquí». 
«Viéneme a propósito contar vn caso particular que aconteció [...]», y se extiende largamente con escaso interés lexicográfico e, incluso, enciclopédico ${ }^{44}$.

Ya había definido con propiedad lexicográfica Covarrubias la palabra biblioteca, que figura como subentrada en el artículo correspondiente al lema BIBLIA del Tesoro, de esta forma: «Biblioteca, la librería», y en la palabra-entrada LIBRERO añade los rasgos semánticos necesarios para completar una definición suficiente; pero, como no se queda contento, en el Suplemento amplía esta definición léxica en el artículo + BIBLIA, con otros desarrollos sintácticos de metalengua del contenido y numerosos suplementos ilustrativos de carácter enciclopédico sobre dicha palabra, concluyendo con la excusa:

Por no ser molesto ni pareçer demasiadamente curioso no refiero aquí las muchas Bibliothecas que a auido [...].

Pero termina por darnos noticia de varias bibliotecas famosas en su época. Casi los mismos argumentos encontramos en los artículos * LAURENCIO, * LEONTOPODIO, * MANLIO.

Un caso extremo se encuentra en el añadido a + IUDIO, ya que, a pesar de que afirma:

Y aunque auía mucho que decir de esta materia solo referire lo que falta a lo dicho tocante a España [...].

Y se extiende a lo largo de siete folios, hecho explicable fácilmente, debido a la importancia de esta palabra en aquellos momentos y al celo de Covarrubias en la defensa de su fe $\mathrm{fe}^{45}$.

Para concluir, y como una muestra más de su humor el artículo + HARPÓCRATES, dios del silencio, comenta con su estilo directo y campechano $^{46}$ :

$\mathrm{Y}$ es dicho notable referido de los antiguos, que para hablar tenemos por maestros a los hombres y para callar a Dios. Este se viene a haçer lugar commún de que yo procuro mucho escusarme por no pareçer que quiero trasladar lo que en otros se hallará fácilmente, y tratando del silencio es justo vsar dél.

${ }^{44}$ Cfr. con el art. del Tesoro GAFO donde dice: «Un poco ha sido largo este discurso; pero estaráse dicho para quando lleguemos a la palabra lepra, cuya famosa especie es la del gafo»; y en el art. de LEPRA se vuelve a extender con más datos enciclopédicos. Cfr. el comentario sobre la voz ESCARAVAJO del Tesoro en la n. 7.

${ }^{45}$ V., respecto a los judíos, en el art. TALMUD del Tesoro su opinión sobre este libro. En cuanto a su proclividad a contar historias, otra muestra similar del Tesoro la tenemos en GALLO: «No pude escusar de trasladar estas dos o tres cláusulas por la elegancia que tienen [...]. Yo te ruego, o pío Letor, no tomes pesadumbre, ni te dé fastidio que le repita en este lugar [...]», y añade tres folios de datos curiosos y eruditos sobre este animal.

${ }^{46} \mathrm{~V}$. la nota 7. 
Por todo lo anterior, comprobamos que Covarrubias era plenamente consciente de que no convenía, como principio general de su metodología, elaborar una obra cuya planta fuese la mera acumulación de los muchos datos que tenía a su alcance en su copiosa librería ${ }^{47}$; sino que, por la naturaleza de los lemas contenidos en la nomenclatura ${ }^{48}$, compuesta por $77.89 \%$ de nombres propios ${ }^{49}$, Covarrubias tuvo que incluir las informaciones enciclopédicas esenciales $-\mathrm{y}$, con demasiada frecuencia, también, datos simplemente anecdóticos- para aclarar el 'significado' cultural ${ }^{50}$ de este tipo de lemas.

\section{E. Modelos de artículos del Suplemento: Tipología de la Información}

En la microestructura del Suplemento encontramos dos tipos básicos de artículos:

\section{El correspondiente a los nombres propios}

${ }^{47} \mathrm{Cfr}$. «Residió en Cuenca — dice el biógrafo anónimo del Libro de la Capilla- treinta y cuatro años [...] Y llegó a juntar una de las insignes y universales librerías de su tiempo», p. 365 del estudio de Angel González Palencia, «Sebastián de Covarrubias y Orozco (Datos biográficos)» en Historias y Leyendas: estudios literarios. Madrid 1942. V. en mi o. c., pp. 1074-1226, la relación de obras y autores que cita.

${ }^{48}$ Cfr. con el listado de «Autoridades en el Suplemento al tesoro de la lengua Española Castellana» de mi o.c.,pp. 1171-1187 donde damos la relación de lemas que no incluyen en sus respectivos artículos autoridad alguna.

${ }^{49}$ V. la nota 38.

${ }^{50} \mathrm{Al}$ respecto, fue muy claro J. Fernández-Sevilla, o. c., pp. 16-17; «El buen lexicógrafo ha de estar compenetrado con los saberes de su tiempo y aun con las corrientes culturales y de pensamiento imperantes en su época. Por más que se pretenda, un diccionario no es - no puede ni debe ser- una obra intemporal ni atemporal». V. también B. Quemada, o.c.,pp. 522-534; George Matoré, Histoire des dictionaires français, París 1968,pp.9-37; Alain Rey, o.c.,pp.56(nota 1) y p. 123;J.Rey-Debove, Étude lingüistique et sémiotique des dictionnaires français contemporains, París 1971, p. 15; J. y C. Dubois, o.c., pp. 8 y 56; M. Alvar, o. c. en nota 7, pp. 164-166; M. Alvar Ezquerra, Proyecto de lexicografía española, Barcelona 1976, p. 20; L. Collignon y M. Glatigny, Les dictionnaires. Initiation à la lexicographie, París 1978, pp. 18-24; A. Rey y S. Delesalle, «Problèmes et conflits lexicographiques», en Langue Française, 43, 1979, pp. 4-26. Christian Buzon, «Dictionnaire, langue, discours, idéologie», en Langue Français, 43, 1979, pp. 27-44, especialmente las pp. 42-44. Sobre la inclusión de los nombres propios en la macroestructura de algunos tipos de diccionarios, cfr. Robert Verdonk, «Contribución al estudio de la lexicografía española en Flandes en el siglo XVII (1599-1705)», BRAE, LIX, 1979, pp. 299-369. F. Lázaro Carreter, «Pistas perdidas en el Diccionario», en BRAE, LIII 1973, pp. 249-259; S. Gili Gaya, p. XXXII del VOX, Diccionario general ilustrado de la lengua española, Madrid ${ }^{3}$ 1973. B. Quemada, o. c. en nota 3, pp. 310-319; J. y C. Dubois, o.c. en la nota 7, p. 65; J. Rey-Debove, $0 . c$. , pp. 33, 69 y 89; y la p. 98 de su colaboración: «Léxico y diccionario» para la obra dirigida por Bernard Pottier, El Lenguaje (Diccionario de lingüística), Traducción y adaptación al español bajo la dirección de M. Alvar Ezquerra, Bilbao 1985; y, también los siguientes trabajos de M. Alvar Ezquerra: a) en el art. cit. en la nota 6, p. 161; b) « ¿Qué es un diccionario?» art. cit. en la nota 3, pp. 115-116; c) Lexicología y lexicografía. Guía bibliográfica, Salamanca, 1983, en su índice de materias, bajo el epígrafe "nombres propios", relaciona el autor el tratamiento que tienen estas palabras en las distintas obras que estudia; d) «Los prólogos del Diccionario [...]», art. cit. en la nota 3, p. 43; e) v. la p. XXXVII del «Prólogo» a la $o . c$. en la nota 13; G. Matoré, p. 42 de la $o . c$. en esta nota; Manuel Seco, o.c., p. 181; Ignacio Bosque, «Sobre la teoría de la definición lexicográfica» en Verba, vol. 9, 1982, p. 114. 
En estos artículos pueden figurar los siguientes elementos ${ }^{51}$, que numeramos por orden de frecuencia de aparición:

1. Descripción-definición ${ }^{52}$.

2. Etimología y glosa etimológica

3. Forma clásica

4. Información enciclopédica

5. Bibliografía

6. Resumen informativo

7. Citas de clásicos.

8. Nivel de uso. Simbología

9. Comentarios diversos

10. Reenvíos.

11. Fraseología

12. Corrección de erratas del Tesoro de 1611.

El orden de aparición a lo largo del artículo no es fijo ${ }^{53}$. Con todo, el elemento que menos suele faltar es la explicación enciclopédica del lema, a la que sigue la etimología, la forma clásica, informaciones eruditas comentadas y las oportunas referencias bibliográficas ${ }^{54}$, acompañadas de las citas correspondientes.

\section{Artículos del léxico común:}

Presentan elementos comunes con los anteriores, tales como los referidos a las etimologías, comentarios eruditos y la correspondiente bibliografía; pero otros elementos son exclusivos de este tipo de palabras:

Elementos que componen estos artículos:

1. Definición

$$
\text { 1. 1. Acepción } 55
$$

2. Etimología

2. 1. Discusión etimológica ${ }^{56}$

2. 2. Término latino correspondiente

3. Nivel lingüístico

4. Familia léxica

5. Indicaciones cronológicas, geográficas, etc.

6. Autoridad (jurídica, temática, literaria)

${ }^{51}$ En general, coincidimos con los tipos de información que encuentra en el Tesoro M. Seco, o. c., pp. 104-105.

52 Por tratarse de nombres propios, no lo hemos rotulado directamente «definición», siguiendo a $\mathrm{M}$. Seco, o. c., p. 105.

${ }^{53} \mathrm{~V}$. los arts. que incluimos después.

$54 \mathrm{~V}$. en mi o.c., pp. 1171-1187, la relación de artículos sin autoridades.

55 En el apartado «Tipos de Añadidos» damos la relación completa de los artículos que añaden nuevas acepciones.

${ }_{56} \mathrm{~V}$. aquí el apartado «Método de incorporación de las etimologías en el Suplemento». 


\section{Resumen enciclopédico \\ 8. Bibliografía \\ 9. Comentarios \\ 10. Fraseología \\ 11. Reenvíos}

12. Corrección de erratas del Tesoro de 1611.

Tampoco en este tipo de artículos encontramos una constante regularidad, pero, generalmente, el elemento más fijo es la definición, que - sin pretender encorsetar el entrañable estilo directo y coloquial de Covarrubias dentro de las actuales teorías de la definición lexicográfic- responde, en los verbos, al tipo de definición sinonímica ${ }^{57}$ y perifrástica; en los sustantivos, a la definición real: descriptiva, teleológica, genética ${ }^{58}$; en los adjetivos, definiciones por sinónimos, significado antagónico ${ }^{59}$ y perifrásticas; en los adverbios, definición por sinónimos o por formas perifrásticas; $y$, en la interjección y las palabras gramaticales ${ }^{60}$ emplea la explicación.

A continuación ofrecemos una calicata de las estructuras más frecuentes en los artículos del Suplemento, según la división que hemos hecho antes y los tipos de definición antes expuestos.

\section{NOMBRES PROPIOS}

* ACHERONTE. Es vn río del infierno según fingen los poetas. Nombre Griego $\alpha \chi \alpha \mathrm{r} \rho \omega \mathrm{v}$. acheron, id est sine gaudio, vel $\alpha \pi \mathrm{o} \tau \omega \alpha \chi \varepsilon \circ \zeta \mathrm{k} \alpha \mathrm{l} \rho \mathrm{\rho} \mathrm{v}$. quasi doloris tristitice que fluuius. Los Mythológicos que moraliçan esta fábula lo atribuyen a las ansias y congojas de la muerte. Verás a Lilio Giraldo y a Natal Comite lib. 3. cap. 6. Diçen los poetas que todas las almas de los difuntos concurren a este río y que las pasa Charon en su barca, como lo cuenta Virgilio lib. 6. Aeneidos.

Portitor has horrendus aquas et flumina seruat,/ Terribilis squalore Charon.
Palabra-entrada.

Entrada nueva.

1. Descripción-definición.

2. Etimología.

4. Información erudito-enciclopédica.

5. Bibliografía.

7. Cita de textos clásicos.

${ }^{57}$ Cfr. Manuel Seco, o. c., pp. 19-22.

${ }^{58}$ Tomamos esta terminología, por estimarìa más apropiada para su aplicación a Covarrubias, de Julio Casares, Introducción a la lexicografia moderna, Madrid 1950, pp. 159-160.

59 V. Julio Casares $o, c .$, p. 160.

${ }^{60}$ V. en mi $o$. c. el apartado «Clasificación de los lemas» pp. 961-990. Tan solo son tres artículos de remisión gráfica al Tesoro o ampliación de datos etimológicos y de uso. 
* ACHILES. Achylles. hijo de Peleo y de Thetis, al qual su madre siendo niño le bañó en la laguna Stygia, por lo qual quedó inuiolable que no pudo recebir herida en todo su cuerpo, excepto las plantas de los pies, que no se le mojaron por auerle çabullido en el agua, tiniéndole asido de ellas. Su fábula es notoria, y sus hacañas çelebradas por todos los poetas especialmente por Homero, y por solo esto fue embidiado de Alexandro Magno Petrarcha soneto, 155.

Giunto Alessandro ala famosa tomba. e. A qualquiera que loamos de valiente por estremo decimos ser vn Achylles, y a los argumentos fuertes y casi indisolubles, e inuencibles, llamamos Achylleos. Achylles es nombre Griego $\alpha \chi 1 \lambda \lambda \eta \zeta$ por ventura de $\alpha \chi 0 \zeta$ achos. dolor. por el que causaba en los contrarios con tantas heridas y muertes: pero en fin fue muerto por Paris con vna saeta que le enclauó en la planta del pie.

* ACTISANES. Rey de Aegypto. Castigó el latrocinio con nueua pena y fue cortar a los ladrones las nariçes y desterrarlos a vn desierto en el qual edificaron vna ciudad y la llamaron Rhinocuram ab excissis naribus: el común vso es cortarles las orejas y esta falta cubren los curiosos con la cabellera. También ay narizes postizas, pero no se disimulan tanto.

+ MÁLAGA (Añade). Los primeros fundadores de Málaga fueron los Phoenices que vinieron con Pigmalión a España. Mariana Lib. 1. Cap. 15. Ganáronla de los Moros los reyes Cathólicos a diez y nueue de Agosto y según otros a ocho año de mil y quatrocientos y ochenta y ocho.
3. Forma clásica.

1. Descripción-definición.

4. Información erudita.

9. Comentarios.

7. Citas.

8. Simbología.

2. Glosa etimológica.

1. Descripción-definición.

4. Información erudita.

9. Comentario humorístico.

Añadido al Tesoro.

4. Información erudita.

5. Bibliografía.

6. Resumen informativo. 
+ ALFONSO (Añade) [fol. 18v-4) De esta sentençia diçen auer naçido el Prouerbio allá van leyes donde quieren reyes [...].

+ BRUTO (Añade) Tras esta palabra se sigue inmediatamente. Vide Lagunam in Dioscoridemen $\mathrm{e}^{\mathrm{a}}$. Ase de pasar al fin del discurso de la palabra BRUXA.

* ANGLIA. Vide INGALATERRA.

\section{LÉXICO COMÚN}

a) Verbos:

* ABSOLVER. Verbo compuesto de $a b$ y soluo.is. Vale desatar, dar a vno por libre, o perdonarle la deuda. Este término vsa la santa madre Yglesia en el perdonar los pecados dichos en confesión al Saçerdote que tiene facultad de Absoluer y remitir pecados: y de allí ABSOLUCrón y ABSUELTO.

* ACELERAR. Del verbo latino accelerare. Vale lo mesmo que apresurar o anticipar alguna cosa. ACELERADO. el súbito y apresurado. ACELERADAMENTE $e^{a}$.

* ACOITAR. En lengua antigua Castellana vale procurar.

* ADUGAR. Vocablo antiguo. vale lleuar del verbo adduco. is. Ley sesenta y tres título quarto partida primera. Mandamos que le prendan e le adugan ante el rey $\mathrm{e}^{\mathrm{a}}$.

+ AÇICALAR (añade) puede traher origen de la palabra Griega $\alpha$ kı $\sigma$. acis que significa punta, y de allí Açicalado que valdrá tanto como afilado y agudo.
11. Fraseología.

12. Corrección de erratas.

10. Reenvío.

2. Etimología.

1. Definición.

3. Nivel lingüístico.

4. Familia léxica.

2. Etimología.

1. Definición.

4. Familia léxica.

5. Indicación cronológica.

1. Definición.

5. Indicación cronológica.

1. Definición.

2. Etimología.

6. Autoridad jurídica.

2.1. Discusión etimológica. 4. Familia léxica. 
+ ACORDAR (Añade) algunas veçes puede sinificar concertar vn instrumento con otro, y entonçes vendrá de la palabra Corda.a. Verás la palabra CUERDA.

+ ADULTERAR.(Añade.) Zeleuco legislador de los Locrenses entre las demás leyes hiço vna en que disponía fuesen sacados ambos los ojos al que cometiese adulterio. Un hijo suyo fue acusado y conuençido de este crimen y holgando todo el pueblo de que por respeto de su padre fuese perdonado, Zeleuco no lo admitió pero sacaron vn ojo a su hijo y a el otro, y ansí se cumplió con la ley y ambos quedaron con vista. Valerio Máximo lib. 6. Cap. 5.

b) Sustantivos:

* ABSTINENCIA. El refrenamiento y priuación voluntaria de alguna cosa que puede redundar en daño y en perjuicio nuestro, moderando las pasiones de la irascible y concupiscible, y algunas veçes sinifica el ayuno. del verbo abstineo es. por refrenarse, compuesto de abs et teneo. es.

* ALFABETO. Alphabetum. vale Abeçedario donde se ponen por su orden las letras empeçando por la alpha y la beta. Verás la palabra Alfa. La dicción Abeçedario contiene en sí las quatro letras A.B.C.D.

* CONCORDIA. Unanimidad y consensu de partes. su contrario es discordia. Vide verbo concordar. El dicho de Sallustio in bello Jugurthino, es muy reçebido. Concordia res parnae crescunt, discordia maximae dilabuntur. Dicitur concordia a corde congruente. Los Romanos le hiçieron

\subsection{Acepción.}

2. Etimología

11. Reemvío.

7. Resumen enciclopédico.

8. Bibliografía.
1.1. Acepción.

2. Etimología.

2.2. Término latino.

1. Definición.

11. Reenvío.

9. Comentario curioso.
1. Definición.

4. Familia léxica.

7. Resumen enciclopédico.

8. Bibliografía. 
templo como lo testifica Tito Liuio Lib. 9. Ab Urbe Condita.

Scyluro Scytha tubo ochenta hijos y estando a la muerte dio a cada vno de ellos vn haçeçito de saetas mandándoles que ansí [...].

* CONDESIJO. Vide verbo Condejar.

* COrME. En la Germanía vale el señor de casa.

+ AFRENTA. (añade). Algunas veces sinifica afrentar requerir o advertir vno a otro delante de testigos para que haga o deje de hacer alguna cosa, diciéndoselo frente a frente y cara a cara, y como deçimos carear de cara, se diçe también afrentar de frente. Vsan de este término las leyes de la partida. Ley 12. et 13.título 17.partida 7.

* AZIGE. Cierta tierra [...]. Yo presumo ser lo mesmo que en Castilla llamamos tierra de Sevilla [...].

+ CARDENILlo. (Añade). Aduierte que en medio de esta dicçión se insirió la palabra CARDENCHA. que auía de seguirse después acabado el discurso, al fin del qual se remata en estas palabras. Los Valencianos le llaman Verdet y luego CARDENCHA de perayle $\mathrm{e}^{\mathrm{a}}$.

* AGRAZ. Es el çumo de la vba [...] y diçe el prouerbio, más vale vaquita en paz que pollos con Agraz [...].

c) Adjetivos:

* ABSURDO se diçe todo lo que es feo e indigno de ser oído. Latine absurdum.
11. Reenvío.

3. Nivel lingüístico.

1.1. Acepción.

6. Autoridad.

1. Definición.

5. Indicación geográfica.

12. Corrección de erratas.

5. Indicación geográfica.
1. Definición.

2. Etimología. 
* ACESORIO. Lo que no es principal del negocio que se trata sino adjunto de la palabra latina accesorium. En Corte llaman posada acesoria la que se da a vn señor para su familia fuera de la principal suya.

d) Pronombre:

* CONBUSCO. Palabra Castellana antigua, vsan de ella las Leyes de estos reynos. Vale lo mismo que con vos, o con vosotros, Latine vobiscum.

e) Preposición:

+ CONTRA. (Añade). algunas veçes no significa contrari-edad y enemiga, sino cosa puesta vna enfrente de otra según el lugar del euangelio, Ire in Castellum quod contra vos est. Virgil. 1. Aenei.

Urbs antiqua fuit Tirij tenuere Coloni Italiam CONTRA.

En Lenguage antiguo vale erga y apud; lo mesmo que cerca de, Ley primera título tercero partida segunda $\mathrm{E}$ por esto pues que en el título ante de este fablamos qual deue el rey ser contra de dios $\mathrm{e}^{\mathrm{a}}$.

f) Adverbio:

* ADURO. y Aduras penas. Término antiguo Castellano que vale tanto como gran dificultad, o con gran dificultad, por la pena y el cuydado que se toma en ajustar la tal cosa y también deçimos absolutamente apenas, latine vix.

g) Interjección:

* ABERNUCIO. Vocablo Barbaro. corrompido del verbo abrenuncio.as. por renunciar con odio y abominaçion alguna
1. Definición.

2. Etimología.

3. Nivel linguístico.

5. Indicación cronológica.

1. Definición-explicación.

2. Etimología.

1. Definición-explicación.

8. Bibliografía.

6. Autoridad.

1. Definición.

2.2. Término latino.

5. Indicación cronológica.

2. Etimología. 
cosa mala y execrable, como en los en los exorcismos al que a de ser bautiçado se le pregunta abrenuncias Sathanae? $\mathrm{e}^{\mathrm{a}}$. y si es adulto responde, abrenuncio y si es infante, respondenlo por el sus padrinos.
1. Definición-explicación.

3. Nivel lingüístico.

\section{F. Tipos de Añadidos}

Del estudio y clasificación de los añadidos a los artículos que ya figuraban en el Tesoro (precedidos en el manuscrito de una cruz [+]) obtenemos datos precisos sobre la forma de trabajar de Covarrubias en este parte de la microestructura, e, indirectamente, inferimos un dato irrefutable sobre la autenticidad del manuscrito, ya que en la alusión que hace Martín de Riquer al manuscrito en la página XII del estudio preliminar ${ }^{61}$ de su edición del Tesoro afirma:

La simple lectura y las fuentes citadas convencen de que este suplemento es obra de Sebastián de Covarrubias; la seguridad absoluta de ello nos la da la voz Covarrubias, en el fol. 113 v. donde se lee: «COVARRUBIAS. Villa principal en el Arçobispado de Burgos, ay en ella Yglesia collegial con su abbad. De este lugar salieron a vivir al reyno de Toledo en tiempo de los Reyes Cathólicos los abuelos del presidente mi señor don Diego de Covarrubias de Leyva, y por aver venido de Covarruvias les dieron el nombre de la patria, pero el nuestro solar es la casa de Leyva».

Y S. Gili Gaya en la página XIX del prólogo del Tesoro lexicográfico ${ }^{62}$ asevera:

Por lo que dice en el artículo Covarrubias es indudable que fue obra del mismo autor. La letra y la filigrana del papel son de la primera mitad del siglo XVII. Debió de componerlo muy poco después de 1611 [...].

[Los subrayados son nuestros]

Esa 'simple lectura y las fuentes citadas' del manuscrito, y los datos que figuran en el artículo * COVARRUBIAS, escrito al margen del citado folio ${ }^{63}$, en el que se apoya también Gili Gaya, pueden confirmarse con las pruebas de correspondencia entre los artículos añadidos del Suplemento para el Tesoro y, de

${ }^{61}$ Martín de Riquer Morera, «Prólogo» al Tesoro de la lengua catellana o española, Barcelona 1943 (Citamos por la edición de la editorial Alta Fulla, Barcelona 1987).

${ }^{62}$ S. Gili Gaya, Tesoro lexicográfico (1492-1726), t. I. Madrid 1960.

${ }^{6.3}$ Véase que en la edición de mi $o . c$. figura el correspondiente símbolo [...] de estar escrito en el margen inferior izquierdo del manuscrito. Creemos que este artículo marginal podría haber sido añadido de forma espuria, como otras anotaciones que tiene el manuscrito como advertimos en «Descripción del manuscrito», pp. 13-30 de mi o. c.; pero las pruebas que aportan los datos internos contestes de la microestructura del Suplemento y del Tesoro no se podrían manipular como un simple artículo fuera de la caja del texto normal. 
esta forma, se refuerza la paternidad del manuscrito por medio de datos internos de ambas microestructuras.

En la planta del Suplemento figuran cuatrocientos cuarenta y tres artículos añadidos (el $20.2 \%$ de la nomenclatura), de los cuales doscientos nueve corresponden a nombres propios, y doscientos treinta y cuatro pertenecen a voces del léxico común ${ }^{64}$.

Hemos clasificado los añadidos en los siguientes grupos, diferenciando, en mayúscula los nombres propios, y en minúsculas los signos lingüísticos, para de esta forma gráfica facilitar la diferenciación y facilitar la consulta de las estadísticas $^{65}$.

I) Tipos de añadidos al Tesoro:

a) Solo amplían la información enciclopédica del Tesoro:

+ ABDALÁ, + acote, + AÇUDA, + adulterar + AGAPITO, + AGREDA, + agua + agüero + aguinaldo, + agnus dei, + alacrán, + ALAGÓN, + ALARCÓN, + ALBARRAÇINC, + ALBIGENSES, + ALBOR, + ALCAÑIZ, + ALCE, + ALCUDIA, + ALDONCA , + ALEMANIA, + ALEXANDRO, + ALFONSO, + ALHAMA, + ALJAFERÍA, + alférez, + almirante, + almófar, + ÁLORA, + ALPUXARRAS, + ALVA, + AMÄIA, + AMBROSIO, + amén, + AMÓN, + AMPURIAS, + AMURATE, + ANA, + ANASTASIO, + anatema, + ANDRÉS, + antojos, + año, + aojar, + ara, + ARGEL, + ARSENIO, + asbesto, + atalaia, + ATENAS, + ATLAS, + atún, + audiencia, + AVERROES, + AUGUSTINO, + AVIA, + AVICENA, + ÁVILA, + AXARQUÍA, + azeite.

+ BAÇA, + BAEÇA, + baibén, + BAIONA, + BALBASTRO, + BALSAÍN, + baptismo, + bermellón, + BARRACAS, + bastida, + BEHEMOTH, + BELILLA, + bellón, + BERMUDO, + BERNARDO, + BETIS, + BILBAO, + biuda, + bívora, + blanca, + BOBADILLA, + bobo, + bollo maimón, + BOLONIA, + bombarda, + BORJA, + bragas, + brasero, + breviario, + brincar, + BRINDEZ, + bubas, + BUCÉFALO, + buhído, + búho, + BURGOS, + BURRIANA.

+ cabello, + CABO, + CABRA, + CABRERA, + CAÇORLA, + cadena, + CALAHORRA, + calças, + CAMUESA, + capitán, + CARLOS, + CARMEN, + CARTAGO, + CASILDA, + CASTILLA, + casulla, + CATALUÑA, + CATÓN, + cavallos, + claustro, + clavo, + COCODRILO, + código, + cogulla, + cola, + cola de cavallo, + COLOSO, + colunas, + comedia, + COMPOSTELA, + confederar, + CORIA, + corniculario, + corona, + cruzados, + CUBA, +

\footnotetext{
${ }^{64}$ Véase el capítulo «La nomenclatura del Suplemento», pp. 905-1001 de mi $o . c$.

65 Véanse las pp. 961-1001 de mi o.c.
} 
CUENCA, + cuervo, + culebra, + curioso, + ÇAYDA, + ÇAMORA, + carabanda, + çebra, + çedaço, + cementerio, + çera, + CERRO, + CERVANTES, + cevada, + CID, + ciervo , + CIPIÓN, + cisma, + ÇISNE, + CÍSTER, + curdo, + charlatán,

+ dado, + DARRO, + delfín, + DEMÓCRITO, + DEMÓSTENES, + derecho canónico, + descalço, + desflorar, + desposar, + desvariar, + DEUCALIÓN, + diablo, + dialecto, + diciplinarse, + DIDIMO, + DIONISIO, + doblas zahenes, + DOMINGO, + DRAGÓN, + DUEÑAS, + DUERO, + DULCE.

+EBRO, + ÉCIJA, + ELCHE, + elección, + emperador, + encubar, + ENEAS, + enebro, + enechado, + ENRRIQUE, + enterrar, + ermandad, + eroico, + escama, escoba, + escriturario, + espejo, + esquivo, + estatua, + ESTELA, + ESTEVÁN, + estola, + estopa, + EVARISTO, + ÉUFRATES, + EUGENIO, + EUSEBIO, + EZQUERRA.

+ FABIANO, + FACUNDO, + FARO, + FÉLIX, + feria, + FERNANDO, + FERNÁN GONÇÁLEZ, + feudo, + FEZ, + fiebre, + FILEMÓN, + FILIPE, + FRANCIA, + FRANCISCO, + FRANCOLÍN, + fuerça.

+ gaitería, + galera, + gallo, + galope, + GARCíA, + garnacha, + GELASIO, + GENIL, + GÉNOVA, + GERIóN, + GIBRALTAR, + gorra, + GRANADA, + GREGORIO, + GUADALQUIVIR, + GUADIX, + guante, + GÜESCA, + GÜETE, + GUINEA, + GUISANDO.

+ hacha, + HARO, + harpón, + HARPOCRATES, + higa, + higuera, + HOMERO, + HORNACHOS, + HUELGAS, + HURRACA.

+ IACOB ${ }^{66},+$ IAÉN, + jesuitas, + IORGE, + IUAN, + judio, + juego, + IULIÁN, + IUNQUERA, + IÁÑEZ, + IBERIA, + IDUBEDA, + imán, + INFANTE, + INTERCACIA, + intérprete, + IVIZA.

+ langosta, + lechugas, + lengua, + lenguage, + LEÓN (ciudad), + león (animal), + leviatán, + LIBRA, + lino, + LIRA, + LISBOA, + lobo (animal), + loba (vestidura), + LONGINOS, + LORA, + LUGO, + LUIS, + LUMBRAL, + LUNA, + LUSITANIA, + llorar, + lloraderas.

${ }^{66}$ Recordamos que el signo paleográfico I, en mayúscula, tiene valor consonántico y vocálico tanto en el Suplemento como en la primera edición del Tesoro; paralelamente, nuestra actual J, mayúscula, no figura nunca escrita en posición inicial en las entradas del Tesoro impreso en 1611 , ni en el manuscrito. Véase también lo que decimos sobre la ortografía del manuscrito y criterios de trascripción en mi $o . c_{\text {., pp. }}$ $31-62$. 
+ MACARIO, + MACROBIO, + MAÇA, + MACHUCA, + MADRIGAL , + maestre, + maiorana, + MÁLAGA, + MALLORCA y MENORCA, + manceba, + MANCHA, + mapa, + maravedí, + MARBELLA, + MARCA, + MARGARITA, + marimacho, + marido, + MARTíN, + MARTOS, + masa, + maxilla, + medalla, + MEDINA, + MELCHISEDECH, + mellizos, + memoria, + MENDOZA , + MERCAR, + MERCURIO, + MIÑO, + misa.

b) Rectifican y amplían la información enciclopédica:

+ abigarrado, + ÁLAVA, + ALCAICERíA, + ALCÁNTARA, + ALGARBE, + ALMERIA, + anatema, + arnequín, + baharí, + CASILDA, + conducho, + emprestar, + escoba, + escuchar, + falcidia, + FRANCIA, + gigote, + loba (vestidura), + mancer, + melena.

c) Añaden otras etimologías al Tesoro:

+ ÁBILA, + acicalar, + adulterar, + ÁFRICA, + afufar, + AGAR, + alançada, + ALDONCA, + aleluya, + ALEXANDRO, + alférez, + ALGARBE, + alicates, + allegar, + ALMERIA, + anchova, + andabates, + arrendar, + ASTURIAS, + atalaia, + ATLAS, + atún, + AZECA.

+ BAÇA, + baharí, + BALSAÍN, + bastida, + BETIS, + BOBADILLA, + bobo, + bodoque.

+ CÁÇERES, + cada, + CALABRIA, + CALAHORRA, + cangilón, + CANTABRIA, + cañón, + capitán, + carnero, + coleta, + COMPOSTELA, + cortar, + cotín, + cuerda, + curioso, + çapato, + carabanda, + ceño, + cerveza, + curdo, + charlatán.

+ DARRO, + delfín, + diadema.

+ ELENA, + entecado, + eroico, + ESCULAPIO, + ESPAÑA.

+ feria, + fidalgo.

+ galope, + ganso, + GÉNOVA, + GERIÓN, + GUADALAXARA, + GUADALUPE, + GUADIANA, + GUADIARO, + GÜETE, + GUINEA. + hanega, + higa, + hongo.

+ IAÉN, + jarro, + IORDÁN, + IÁÑEZ.

+ ley, + león ( animal), + loba (vestidura), + LUSITANIA. 
+ mancer, + MANCHA, + MARBELLA, + marlota, + mascar, + melena, + mesón.

d) Añaden nuevas acepciones a los artículos del Tesoro:

+ acordar, + acicalar, + afrenta, + afrontar, + alacrán, + alançada, + alférez, + almófar, + amén, + ana, + andabates, + antojos, + apuesta, + arfil, + armiño, + arrendar, + azitara.

+ bodoque, + bollo maimón, + bordón, + brial, + buhído, + buzano.

+ cada, + CALABRIA, + calças, + califa, + calpe, + can, + cañón, + caro, + carpintero, + catedrático, + cavallero, + cocar, + coleta, + confederar, + contra, + corona, + culebra, + curioso, + çatico, + cementerio, + cítola.

+ derrengar, + desmallar, + desmontar, + desvariar, + disponer.

+ ELCHE, + embarrar, + encubar, + enrrizar, + espadilla, + estatua, + EUROPA.

+ forera.

+ ganar, + gasajo, + gato, + gaván.

+ hermoso, + homecillo.

+ jarcias, + juego.

+ marca (señal), + marimacho, + masa, + mensage, + miz.

e) Corrigen erratas del Tesoro:

+ arnequín, + ATENAS, + BRUTO, + cardenillo, + casa, + católico, + çaraças, + escoba, + hijo.

f) Remiten a otras entradas del Tesoro o del Suplemento:

+ azedia, + fanega, + gamo, + GUADARRAMA, + IBIÇA.

II) Análisis de estas clasificaciones

De los cuatrocientas cuarenta y tres artículos añadidos, trescientos cuarenta y tres, el $77.4 \%$, los dedica Covarrubias a ampliar la información enciclopédica, 
que ya representaba el $68.38 \%$ de la nomenclatura del Suplemento, pues dedica mil quinientos tres artículos a nombres propios ${ }^{67}$. Le sigue la información sobre las etimologías con noventa artículos y la información lingüística con setenta artículos. Por último, dedica catorce artículos a corregir o completar datos del Tesoro.

El motivo de la abundancia de información enciclopédica la volvemos a encontrar en lo sensible que fue Covarrubias a las reseñas orales que se le hacían de su obra impresa, como la inserta en el artículo:

+FERNANDO. (Añade.) Atemoriçado con la multitud de cosas a que auía de acudir desconfiando pudiera llegar al fin y cumplimiento de esta obra fui atrancando mucho de lo que auía de deçir y por esta causa me an echo cargo algunos curiosos de auer sido tan sucinto particularmente en esta palabra Fernando y en las demás de los reyes de Castilla León y Nauarra. Y pues dios a sido seruido de darme vida para poderlo enmendar, aunque continuando mi poca salud, e querido satisfacer a su deseo, y ansí digo que don FERNANDO ${ }^{68}[\ldots]$.

Esta reseña de «algunos curiosos» [que hemos subrayado] es suficientemente clara para justificar que los artículos + ALFONSO, + BERMUDO, + BERNARDO, + ENRRIQUE, + FERNANDO, + FERNÁN GONÇÁLEZ + FELIPE, + GARCÍA e + IVAN salgan a un promedio de más de tres folios de información ${ }^{69}$ complementaria para los respectivos artículos del Tesoro impreso de 1611 .

\section{G. Remisiones internas en el Suplemento al Tesoro de la Lengua Castella- na o Española}

Covarrubias pensó el Suplemento para que fuese impreso conjuntamente con el Tesoro, en una futura edición que ya tenía pensada como refiere en el último párrafo del prólogo 'Al Letor':

Yo pido con toda humildad y reconocimiento de mi poco saber, que todo aquello que errare, se me emiende con caridad, y se me aduierta para otra impressión $^{70}$.

y prueba de ello, son las numerosas remisiones internas que existen a la primera edición del Tesoro en el Suplemento.

Dejando aparte los artículos que son continuación o añadidos a sus entradas respectivas en el Tesoro, ya sea para subsanar errores, ya para completar datos, lo que podríamos llamar «Suplemento a las erratas que el Autor ha hallado, ultra

\footnotetext{
${ }^{67}$ Véase el resumen estadístico en mi o.c., pp. 990-992.

${ }^{68}$ En nuestra edición del Suplemento, o. c., s. v. + FERNANDO.

${ }^{69}$ Otras estadísticas de tipo parecido, incluimos en las pp. 1074-1075.

${ }^{70}$ En el fol. I v. de la ed. del Tesoro de 1611.
} 
de las ya impresas en el Tesoro» ${ }^{71}$; los reenvíos del Suplemento se efectúan con fórmulas variadas.

\section{I.- Fórmula de Remisión ${ }^{72}$}

a) Fórmulas básicas de remisión:

a. 1. Remisión gráfica:

En el artículo + ÁBILA del Suplemento remite con la fórmula «vide infra verbo ÁVILA» a la voz + ÁVILA (fol. 62r), y ambos lemas tienen su correspondiente artículo temático. En el Tesoro, la entrada ÁVILA, sin desarrollo temático, remite con «Vide Áuila» ${ }^{73}$ al lema ÁBILA, y aquí inserta la correspondiente información a este lema. Se trata, pues, simplemente de una remisión de grafía.

a. 2. Remisión temática:

En el artículo * ABSINTIO remite a ASSENSIOS con el reenvío «Vide verbo ASSENSIOS». Esta voz aparece en el Tesoro, pero no en el Suplemento, y en el artículo ASSENSIOS se encuentra toda la información semántica referida al lema* ABSINTIO.

a. 3. Remisión por derivación:

En el artículo + ACORDAR remite con «Verás la palabra CVERDA» tanto al Tesoro como al Suplemento, pues en ambos aparece esta palabra en la nomenclatura. Relaciona por derivación los dos lemas y de esta forma completa sus respectivos artículos.

Estos son los tres tipos básicos de remisión en el Suplemento: reenvíos de naturaleza gráfica, por derivación o temática al Tesoro, al Suplemento mismo, o a ambos. Al final damos la relación de estos; pero antes estudiamos pormenorizadamente, debido a su excepcional importancia, los casos especiales que ofrecen algunas muestras de la forma de trabajar de nuestro lexicográfo.

${ }^{71}$ Como dice Martín de Riquer en la p. X del «Prólogo» a su ed. del Tesoro, algunos ejemplares llevan una segunda lista de erratas que se titula «Erratas que el Autor a hallado vltra de las ya Impresas, en el Tesoro de la Lengua Española». Así figura en el volumen de la edición de 1611 que posee The Hispanic Society of America; nosotros hemos manejado la edición microfotografiada que hizo en 1927 en Nueva York dicha Sociedad.

${ }^{72}$ Los lemas del Suplemento los escribimos siempre con el asterisco o cruz que llevan en el manuscrito y de esta forma los diferenciamos de las palabras del Tesoro. Respetamos las grafías de los reenvíos y los lemas correspondientes.

${ }^{73}$ En la primera lista de ERRATAS DEL TESORO DE LA/ lengua Española castellana, del Licenciado don/Seuastian de Couarruuias Horozco/Madrid 1611. se corrige «Auila» por «Abila» que es como figura en la nomenclatura del Tesoro. 
b) Casos especiales:

En artículo * ACRISIO reenvía de la siguiente forma: «Verás la palabra Danae y la palabra Perseo», ninguna de estas dos palabras figuran en la nomenclatura del Tesoro. El lema* DANAE y el artículo correspondiente sí figuran en el Suplemento, pero la entrada Perseo, ya que el manuscrito solo alcanza hasta el lema * MOISÉS, no figura en este volumen, lo que, en principio, induce a pensar, bien en la existencia de otro volumen, bien en que Covarrubias tenía papeletizada esta palabra para incluirla posteriormente en la planta de la futura edición conjunta del Tesoro y el Suplemento como lema nuevo; pero le faltó tiempo y salud ${ }^{74}$. Podría caber una tercera posibilidad: que fuese una remisión perdida, una pista perdida.

Igual ocurre en la remisión a la dicción alfa en el artículo * ALFABETO, pero no se encuentra, como entrada, ni en la nomenclatura del Tesoro ni en la del Suplemento; además, en el artículo + ALFONSO (fol. 22v.) remite a Poncia, que tampoco aparece en el Tesoro. También remite a Poncia en el artículo correspondiente a + BELILLA.

Más casos encontramos en el artículo * ARTOFILAX que remite con la frase: «Vide supra verbo Arcas, et infra osa mayor y menor» que no se registran en la nomenclatura del Tesoro ni en la del Suplemento ${ }^{75}$.

También nos encontramos con que en + BÚHO remite a Nabuchodonosor, en * CINQUESMA, a Pentecostés y * EURIALO, a Niso; o en + GUADARRAMA envía a Oróspeda, y en * MAXIMILA, a Montano, que no figuran en la nomenclatura del Tesoro; y el manuscrito solo abarca hasta * MOISÉS.

En el artículo + CEÑO reenvía a sobrecejo, que no aparece como entrada en el Tesoro, aunque sí se encuentra como subentrada en artículo CEJA.

Que Covarrubias tenía intención de concluir el manuscrito incompleto se ve más claramente en casos como * HIPODAMIA, donde dice: «Lo demás de Pelope se dirá en su lugar», como esta voz no figura en el Tesoro, lógicamente Covarrubias pensaba llegar a esta palabra, como también lo piensa en las entradas * HYREO que remite a Orión, e * ILIA, que reenvía de esta forma: «Verás la palabra Rómulo» y ambas palabras no aparecen en la macroestructura del Tesoro.

Otras veces Covarrubias hace remisiones simultáneas al Tesoro y a la futura continuación del manuscrito en la que daría entrada a una palabra que figuraba ya en la microestructura del Tesoro $^{76}$, así en + INFANTE dice: «[...] verás en la palabra cabezón y en la palabra Mudarra», hechas las consultas, observamos que en el Tesoro, en el artículo correspondiente a cabezón, se refiere al tal Mudarra, pero esta palabra no figura como entrada en el Tesoro, y, repetimos, el manuscrito alcanza hasta * MOISÉS.

\footnotetext{
74 Véase lo que dice en la voz * IEDRA y en mi art. cit. antes.

75 Aparece Arcas en el Tesoro, pero no es el personaje mitológico al que se refiere Covarrubias.

76 Véanse las pp. 907-915 de mi $0 . c$.
} 
c) Otras fórmulas latinas de remisión:

c. 1. Fórmulas desarrolladas:

En el artículo [*] ACIS reenvía con: «Vide supra verbo ACRIS», que, efectivamente, figura dos folios antes en el manuscrito.

En * LEDA remite de esta forma: «[...] Cástor y Clitemnestra. Vide suis locis.»: ambas están en el Suplemento, pero en el caso de Clitemnestra, con la grafía «Clitenestra».

* ADONAI remite con la frase «Vide verbo DIOS et verbo DON». que figuran en el Tesoro.

* ALASTOR envía con otra fórmula distinta: «Vide verbo cauallos in additionibus» que se refiere a los añadidos al Tesoro que figuran en el mismo manuscrito, como se puede ver en el artículo correspondiente a + CAVALLOS.

c. 2. Fórmulas abreviadas:

Los artículos * FARAMUNDO, * FLEGEO y * LICOMEDES remiten con «Vide $\mathrm{v}^{\circ}[\ldots] » ;$ MAUROS con: «ve. MAURITANIA $\mathrm{y} *$ BENEDICTO con: «ve. vo. BENITO».

d) Fórmulas directas:

Contrastan con las anteriores fórmulas tradicionales y escuetas, otras coloquiales y directas como las de * FARMACOTROFOS que remite con «Notarlo as en la palabra veneno», o «[...] Aja o Axa, pudo ser nombre propio según tenemos dicho en la palabra Axa» en el lema * GUADAXA; en * HESIONE: «[...] como más largamente se verá in verbo Laomedonte ${ }^{77}$; y, por último, en + IVAN (fol. 247r. líneas 3-4) emplea la fórmula: «Argantonio vivió muchos años como verás en su lugar». ARGANTONIO se incluye en la nomenclatura del Suplemento.

e) Pista perdida:

Hemos encontrado un caso de remisión círcular en * IARAÍZ que remite a XARAÍZ, lema que aparece con esta grafía en el Tesoro, pero que no define, ni da información, tan solo dice: «Vide supra jarayz», variante ortográfica, que no figura en el Tesoro ${ }^{78}$.

${ }^{77}$ En la nomenclatura del Suplemento aparece LAOMEDÓN, pero en el artículo de este lema figura la dicción LAOMEDONTE.

78 Tampoco figura en los índices de John M. Hill, Index Verborum de Covarruvias Orozco: Tesoro de la lengua castellana, o española. Madrid, 1674-1673, Bloomington, 1921; ni en el índice que figura al final de la ed. del Tesoro de Martín de Riquer. 
Paralelamente, el artículo ZÉFIRO del Tesoro reenvía a Céfiro, entrada que no se halla en él, pero sí en el Suplemento con la grafía * ÇÉFIRO, que a su vez remite a * FAVONIO, donde ya, por fin, incluye la información oportuna.

En resumen, por una parte, las fórmulas de reenvío son variadas, como corresponde al estilo directo y llano de nuestro lexicógrafo, y pocas son las pistas perdidas para las dimensiones de la obra y la avanzada edad de su autor; por otra, queda claro, a la vista de los datos analizados arriba sobre la colación de las remisiones con las nomenclaturas del Tesoro y del Suplemento, que Covarrubias tenía inventariados más lemas para su ulterior inclusión en la copia manuscrita definitiva que debía enviar a la imprenta.

\section{II.- RELACIÓN COMPLETA Y TIPIFICADA DE REMISIONES ${ }^{79}$ :}

1) Remisiones al mismo Suplemento:

* ALCIONE ${ }^{80}, *$ ALICARNASEO, * ANFIARAO, * ANTÍOPA, * APIO, * ARGOS, * ARISTÓGENO, * ASTIAGES, + AZEDÍA; * BUENA DIOSA, * CANANEO $*$ CANDAULES, * CANÍCULA, * CAZLONA, * CORNELES, * CORONIS, * CRISORROAS; * ÇÉFIRO, * ÇEIS, * CERAUNOS, + CURDO, * DUARTE, + EBRO, * EBRÓN, * EGISTO, * EMANUEL, * ESPEIO; * FINEO, * FLEGEO, * FOCENSES, + GAMO, * GANGES, * HEBRO, * HELES, * HONORIO, * HYPERMENESTRA; * HYPSI-CRATEA, * HYRCANIA, * IBERA, * IFIS, * ÍNCUBOS, * INO, * LICAMBES, * LICAS; * LICOMEDES, * LOIBA; * LORENCIO, * MANUEL, * MARCELO, * MAR MUERTO, + MARIMACHO, * MAUROS, * MEDIA, * MEIE, * MERA; * MERLÍN.

2) Remisiones al Tesoro:

* ALCIONE, * ALECTO, * AMASIS, * ANGLIA, * AQUARIO, * ARECIO, * ARISMÉTICA, + AZEDÍA, * AZÉFALO, * BABEL; * BAQUETA, * BAXO, * BERZEBÚ, * BIBARRAMBLA, + BODOQUE, * BRIGO, + CALÇAS, * CANTERO, * CARABELA, * CARIA, [*] ClOTO, * CONDESIJO + CONFEDERAR; * CERASO, * CERE, * CHORIÇO, * DURIA, + ÉCIJA, * ECÓNOMO $*$ EMPAREDAR, * EXPLORADORES, + FACUNDO; * FALANXE, * FARAMUNDO, * FARMACOTROFOS, * FASIS, * FAUNOS, * FINCAR, * FUNERAL, * GALANTE * GALERITA; * GALO, * GÓLGOTA, + GUADALAXARA, * GUADAXA,

${ }^{79}$ Escribimos los lemas con los caracteres que figuran en la ed. del Tesoro de 1611 y en la ed. del Suplemento de mi o.c.

${ }^{80}$ Remite con esta fórmula: «Verás la palabra Ceyx y la palabra Halçiones», pero figura en el manuscrito con la grafía ÇEIS. 
* GUATARO, + GÜETE, + GUMENA, * HATO, * HESPERIA; * HUNOS, + IVAN, * LACHESIS, * LAMA, * LETE, * LOTÓFAGOS, * MAGEDA, * MANQUADRA, * MANSESORES, * MANTUA, * MAURITANIA, * MAUSOLO,$*$ MAZNAR, * MELNA, * MERCENARIO, * MINOS, ${ }^{*}$ MIRMIDONES.

3) Remisión simultánea al Tesoro y al Suplemento por figurar el lema en ambas nomenclaturas:

* ALECTRIÓN, + ANA, * ARCADIA, + BARBASTRO, + BOLLO MAIMÓN, * CRITIS, * CISALPINA, * DOMINICO; * EPEO, + FANEGA, * FELSINA, + FRANCIA, + HIGA, + IBIÇA ${ }^{81}$, * ILLÁN, * MéNADES, * MENTESA.

\section{EN RESUMEN:}

- Covarrubias declara, artículo tras artículo, su forma de trabajar la microestructura. En cuanto a las etimologías, su 'instituto', no deja de consultar la bibliografía que encuentra a mano: las últimas novedades, como la obra de B. José Aldrete, Del origen y principio de la lengua castellana o romance (1606), las incorpora en los márgenes del manuscrito.

- No duda en confesar su ignorancia respecto a algunas dicciones, que aún hoy siguen siendo oscuras y se les asigna origen onomatopéyico; luego, según las teorías etimológicas de la época, tal como prueba Lope Blanch, no fueron tantos los disparates etimológicos de Covarrubias; más bien, no debemos dejarnos llevar, al considerar las ideas de Covarrubias sobre las etimologías, de la visión moderna sobre esta materia, y considerar en sí los datos que de este tipo hemos entresacado y analizado.

- Nuestro lexicógrafo no se conforma con el primer dato que encuentra, sino que busca y rebusca, contrasta datos y los discute. Cuando no los encuentra en los libros, pregunta a personas peritas en la materia, como a su amigo el arabista Diego de Urrea, tal como hoy haría un lexicógrafo: buscar la colaboración de expertos en las distintas ramas del saber. $Y$ en todos estos casos, ya que no es amigo de lo ajeno, deja constancia en el papel de cuáles son sus fuentes escritas $\mathrm{u}$ orales.

- Incluso nos revela en la microestructura de su obra las causas de esta forma de trabajar. Así, la curiosidad de rastrear acepciones nuevas tiene en él un doble origen: el instinto de todo buen lexicógrafo y la afición por la lectura y traducción de los poetas clásicos.

${ }^{81}$ En el Tesoro, (Madrid 1611, fol. 509v.) la grafía del lema es «IVIZA», en el art. correspondiente la grafía es «Ibiza»; en el Suplemento aparecen las siguientes: IBIÇA, IVIÇA (fol. 253v. línea. 15) e IVIZA (fol. 263r. 1. 19). 
- Indirecta y noblemente, Covarrubias deja caer la fama que ya tenía en su tiempo de experto en desentrañar significados oscuros.

- Covarrubias era consciente de que no convenía, como principio general de su metodología, tanta acumulación de datos enciclopédicos, pero, la propia naturaleza cultural de los nombres propios y su natural inclinación a la erudición, le hacían caer en ese enciclopedismo tan peculiar y diferenciador de su obra.

- La estructura de los artículos no es constante, pero claramente se aprecian dos modelos básicos: los dedicados a los nombres propios y los del léxico común; a la vez, estos presentan similares elementos: definición, etimología, comentarios eruditos y citas. Covarrubias suele explicar las dicciones con sinónimos o con definiciones enciclopédicas y perifrásticas.

— La tendencia enciclopedista de Covarrubias se acentúa en los artículos que son añadidos para continuar la información que encabezaba el mismo lema en el Tesoro; pues, de estos artículos, el $77.4 \%$ lo dedica a ello, y les siguen los artículos que contienen información etimológica (noventa artículos), información lingüística (setenta artículos); y a la corrección de erratas del Tesoro destina nueve artículos. Estos mismos artículos son prueba concluyente de que el Suplemento es efectivamente obra de Covarrubias, ya que los datos externos de la obra: la portada, y el artículo * COVARRUVIAS, escrito en el margen del folio, podrían haberse añadido por algún anónimo continuador del Tesoro; pero falsear esta parte de la microestructura es tarea ardua y complicada.

- El manuscrito presenta un complejo sistema de reenvíos al Tesoro y al mismo Suplemento. Tan solo hemos encontrado una pista perdida y varias remisiones a secciones de las letras $\mathbf{O}$ y $\mathbf{P}$ de un segundo volumen del inconcluso Suplemento (que solamente abarca hasta * MOISÉS). 